\title{
Species richness, cultural importance, and prioritization of wild spices for conservation in the Sudano-Guinean zone of Benin (West Africa)
}

Konoutan Médard Kafoutchoni ${ }^{1,2,3^{*}}$ (D), Rodrigue Idohou ${ }^{2,3}$, Anthony Egeru ${ }^{4}$, Kolawolé Valère Salako ${ }^{2}$ (D), Clément Agbangla', Aristide Cossi Adomou ${ }^{3,5}$ and Achille Ephrem Assogbadjo ${ }^{2,3}$

\begin{abstract}
Background: Spices have always been used for their flavor-enhancement characteristics and for their medicinal properties. In Benin, scientific research on spices is scarce, despite their importance in the local population's daily needs. This study investigated the diversity of wild spices and documented the associated traditional knowledge that can be used for their valuation, domestication, and sustainable management in the Sudano-Guinean Zone of Benin.

Methods: Data were collected during field expeditions using semi-structured interviews in ten localities across the three phytodistricts of the zone. Species richness and Shannon's diversity index were estimated using species accumulation curves. Use report (UR), cultural importance, use value (UV) index, and informant consensus factor ( $F_{\mathrm{ic}}$ ) were used to assess traditional knowledge on wild species, their local importance, and informants' agreement among sociolinguistic groups. Priority wild spices were finally identified using an approach combining eight criteria (native status, economic value, ethnobotanical value, global distribution, national distribution, in-situ and ex-situ conservation status, legislation, and threats assessment) in four prioritization methods (point scoring procedure, point scoring procedure with weighting, compound ranking system, and binomial ranking system).

Results: A total of 14 species, belonging to 12 genera and 9 families, were inventoried. The most prominent families were Zingiberaceae (21.43\%), Annonaceae (21.43\%), and Rutaceae (14.29\%). More than 200 specific uses were reported, with the Tchabè people holding the greatest level of knowledge (70 uses; UR $=5.70 \pm 0.33$ ).

The culturally most important spices differed among sociolinguistic groups. Most of the informants agree on the use of the species among $\left(F_{\mathrm{ic}}=0.72-0.98\right)$ and across the considered use categories $\left(F_{\mathrm{ic}}=0.88-0.99\right)$. The highest UV were registered for Aframomum alboviolaceum (UV=0.93), Lippia multiflora ( $U V=0.76)$, and Aframomum angustifolium $(U V=0.18)$. Overall, people perceived wild spices as declining due to agriculture, grazing, and drought. Five species, A. alboviolaceum, L. multiflora, Monodora tenuifolia, Xylopia aethiopica, and Z. zanthoxyloides, were the most prioritized for conservation.

(Continued on next page)
\end{abstract}

\footnotetext{
* Correspondence: k.medard@gmail.com

'Laboratoire de Génétique Moléculaire et d'Analyse des Génomes (LGMAG),

Faculté des Sciences et Techniques, Université d'Abomey-Calavi, BP 142,

Abomey-Calavi, Bénin

${ }^{2}$ Laboratoire de Biomathématiques et d'Estimations Forestières (LABEF),

Faculté des Sciences Agronomiques, Université d'Abomey-Calavi, 04BP 1525,

Cotonou, Bénin

Full list of author information is available at the end of the article
}

(c) The Author(s). 2018 Open Access This article is distributed under the terms of the Creative Commons Attribution 4.0 International License (http://creativecommons.org/licenses/by/4.0/), which permits unrestricted use, distribution, and reproduction in any medium, provided you give appropriate credit to the original author(s) and the source, provide a link to the Creative Commons license, and indicate if changes were made. The Creative Commons Public Domain Dedication waiver (http://creativecommons.org/publicdomain/zero/1.0/) applies to the data made available in this article, unless otherwise stated. 


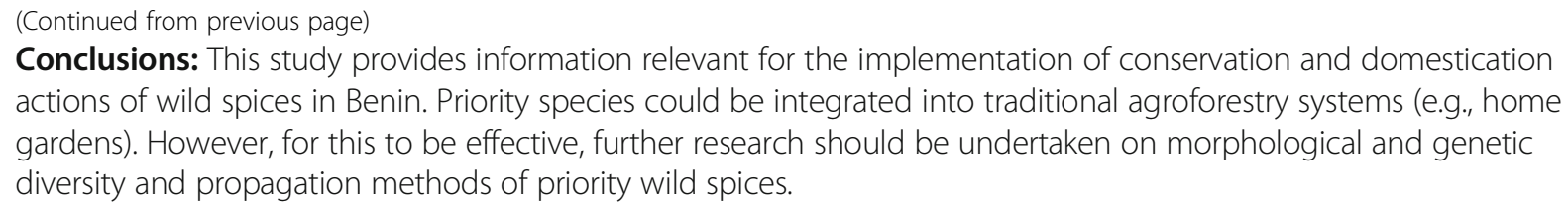

\section{Background}

Biodiversity provides goods and services that sustain human life [1]. Yet, biodiversity is declining at unprecedented rate, which has adverse effects on human wellbeing. The quest to maintain the provisioning power of biodiversity has led to the development of multilateral environmental agreements (such as the Convention on Biological Diversity) and to increasing conservation efforts at country level aimed at slowing depletion [2]. In Benin, attention has been dedicated to the conservation of biological diversity and sustainable use of natural resources [3, 4]. So far, non-timber forest products (NTFPs) are among the most studied groups. Rural households in sub-Saharan Africa do rely on them for subsistence and trade [5]. The NTFPs are important in ensuring food security, meeting medicinal needs, and providing sources of income [6], especially in periods of drought and starvation [7]. However, owing to a changing climate [8] and anthropogenic activities such as agriculture, deforestation, overexploitation, bush fires, and livestock grazing, the NTFPs are threatened by dramatic habitat loss and changing ecologies [9].

Non-timber forest products include different taxonomic and functional groups including wild spices. A spice is "any dried, fragrant, aromatic and pungent edible vegetable or plant substance, in the whole, broken or ground form, which contributes flavor; whose primary function in food is seasoning rather than nutritional, and which may contribute relish or piquancy to foods or beverages, that is true to name and from which no portion of any volatile oil or other flavoring principle has been removed, or to which no additive or spent spice has been added" [10], except for onions, garlic, and celery [11]. Spices have long been valued for their flavorenhancement characteristics and their medicinal properties [12]. They have proven effective in the treatment of various ailments including cough, fever, paralysis, infertility, urinary disorder, tooth ache, snakebite, menstrual disorder, and diabetes among others [13, 14]. They are also important in reducing the incidence of chronic diseases [12]. Many wild spices are rich in various bioactive compounds including alkaloids, polyphenols, flavonoids, steroids, and essential oils, which confer pharmacological potential to them. Some species are rich in key nutrients such as phosphorus, iron, calcium, and magnesium, and constitute a qualitative nutritional source for the local communities [15]. However, since several wild species are under threats of extinction, any action targeting their domestication and sustainable management is welcome.

Sustainable management of wild spices requires their documentation. This is a fundamental first step that helps in revealing the resource base for their better management. The relationship between plant species and their use by local communities is recognized as a central question in conservation science [16]. As such, understanding the determinants of the use of plants by rural communities has become a major concern in ethnobotanical studies [17, 18]. Traditional knowledge can help to clearly understand the different uses and processes developed by local communities over generations and is capital for the valuation of plant species [19]. Therefore, documenting the knowledge of local populations on wild spices is crucial as this information can help in the efficient valuation of these resources at a local level while considering different cultures across the study area.

Since financial resources for conservation activities are often limited, it is important to establish priority species to be conserved [20]. This allows conservationists to know which taxa should be primarily targeted for conservation-those that are not priority and those for which there is insufficient information to know whether or not they are priority for conservation [21]. Prioritization of wild spices is thus essential for their active conservation as it will help optimal use of available resources.

The main objective of this study was to assess the diversity of wild spices and document the associated traditional knowledge that can be used for their valuation, domestication, and sustainable management in the Sudano-Guinean zone of Benin. Specifically, the study (i) assessed the diversity of the wild spices, (ii) assessed the traditional knowledge pertaining to the species, and (iii) documented priority species deserving urgent conservation measures in the Sudano-Guinean zone of Benin.

\section{Material and methods}

\section{Study area}

The study was conducted in the Sudano-Guinean zone (SGZ) of Benin (Fig. 1). The area lies between $7^{\circ} 30^{\prime}$ and 


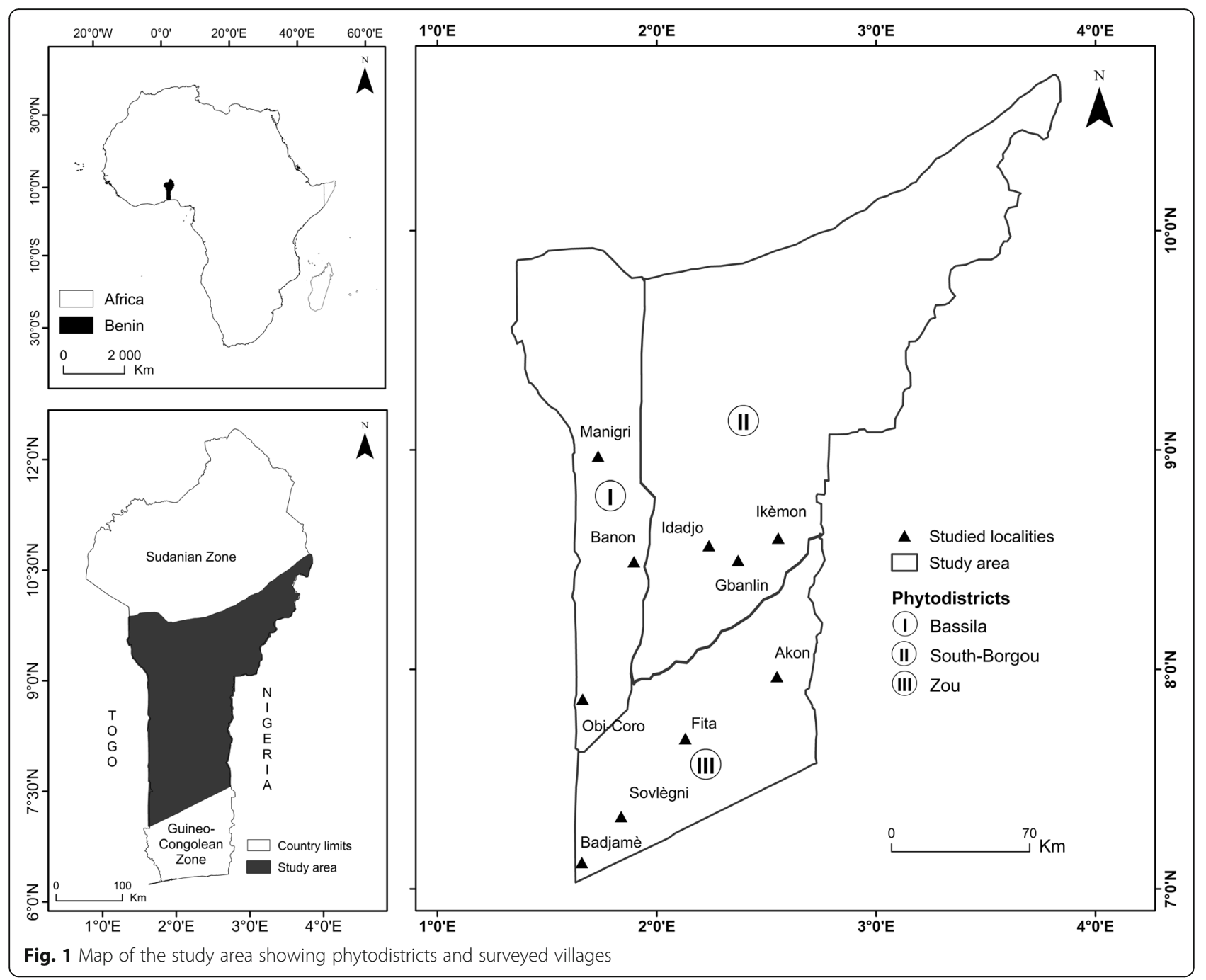

$9^{\circ} 45^{\prime} \mathrm{N}$ and extends from the district of Dassa to the district of Bembèrèkè. The rainfall regime is bimodal with a tendency to unimodal. The mean annual rainfall varies from 1100 to $1300 \mathrm{~mm}$ [22]. The relative humidity varies between 31 and $98 \%$ while the annual temperature ranges from 25 to $29{ }^{\circ} \mathrm{C}$ [23]. The zone is subdivided into three phytogeographical districts: Bassila, Zou, and South-Borgou. The phytodistrict of Bassila covers 9\% of the national territory and is characterized by an annual rainfall of between 1200 and $1300 \mathrm{~mm}$ [24]. The soils are ferrallitic with concretions and breastplates. The vegetation is characterized by semi-deciduous forest, woodland, and riparian forest. The species richness of this phytodistrict is estimated to be 450 species with several rare plants of immense importance [25]. The phytodistrict of Zou occupies 9\% of the national territory with rainfall of between 1100 and $1200 \mathrm{~mm}$ and ferruginous soils on crystalline rocks [24]. It is characterized by dry forest, woodland, and riparian forest which arbor a total of 350 species [25]. The phytodistrict of South-Borgou covers $22 \%$ of the country and has a unimodal rainfall averaging $1200 \mathrm{~mm}$ [24]. South-Borgou has ferruginous soils on crystalline rocks and its vegetation is characterized by dry forest, woodland, and riparian forest with 340 plant species [4]. The main sociolinguistic groups occupying the area are Fè, Fon, Idatcha, Mahi, Tchabè, Nago, Bariba, Anii, and Lokpa [26, 27]. The main activities of those groups are extensive agriculture, animal husbandry, and uncontrolled exploitation of woodlands and gallery forests [28].

\section{Sampling}

The presence of wild spices across Benin was reported by Akoègninou et al. [29]. A brief preliminary survey was undertaken in November 2015 throughout ten localities randomly selected in the study area. Uses by diversity of sociolinguistic group and the effective presence of wild spices was used as the main criteria in selecting localities in each phytodistrict. Random selection was used after selecting localities that met these criteria. In 
each locality, 30 informants [30] were asked if they knew or made use of at least one wild spice in their household. The proportion $p$ of positive answers was used to compute the sample size $n$ for each locality using the normal approximation of the binomial distribution [30]:

$$
n=\frac{U_{1-\alpha / 2}^{2} \times p(1-p)}{d^{2}},
$$

with:

- $U_{1-\alpha / 2}$ the value of the normal random variable corresponding to a probability value of $1-\alpha / 2$. For a probability value of 0.975 (or $\alpha=0.05$ ), $U_{1-\alpha / 2}=1.96$

$-d$ the margin error of the estimation of any parameter to be computed from the survey and was fixed at 0.08

From the formula above, the number of informants randomly considered throughout the study area (all localities considered) was 218 informants including 108 women (Table 1). Ethnobotanical surveys were carried out during 6 months from March to August 2016.

\section{Data collection}

Data were collected through field exploration and individual semi-structured interviews using questionnaire. The questionnaire was twofold: the first part assessed sociodemographic characteristics of informants (name, sex, age, sociolinguistic group, and main activity) while the second part was concerned with their knowledge on wild spices. Each informant was asked to list, using his local name, the wild spices that he (or she) knew and/or used. For each species, data on the meaning of the name, the category of use (food, medicinal, ceremony, cultural, other), the plant parts used, the description of uses, the main habitats where the species is encountered, the local perception of its population dynamic over time (declining, stable, or increasing), the perception of the nutritional value of the species, and its economic value (low, average and high) were gathered during the surveys. Interviews were recorded and conducted entirely in the local language of the informants, with the help of a translator when and where necessary. Individual semi-structured questionnaire interviews were followed by direct observations on the field (home garden, field, fallow, savanna, or forest) accompanied by key informants to observe the species in their natural habitat or in cultivation while minimizing the risks of erroneous identifications. The species were photographed, collected, and pressed for identification in the herbarium [31]. Literature was used to collect data regarding the species origin, its global and national distribution, its conservation status (in situ and ex situ), existence of legislation, and threat assessment, for prioritization purpose. Scientific articles, the flora of Benin [29], the Biodiversity Atlas for West Africa [25], the IUCN online database [32], the Red list of threatened plant species in Benin [4], and the online database of the Plant Resources of Tropical Africa [33] were used as complementary sources of data.

\section{Data analysis}

Collected specimens were identified at species taxonomic level and their life form checked using the illustrated reference book of Arbonnier [34], the Analytic Flora of Benin [29], and the expertise of a specialist of the National Herbarium of Benin. The chorological type of each species was determined following White [35]. Relative frequencies were computed by species, botanical family, life form, and chorological type in order to generate tables and bar plots at levels of phytodistricts and sociolinguistic groups. To estimate wild spices richness, species compositions as

Table 1 Sample size by locality, sociolinguistic group, phytodistrict and gender

\begin{tabular}{|c|c|c|c|c|c|c|c|c|c|}
\hline \multirow{2}{*}{$\begin{array}{l}\text { Country } \\
\text { district }\end{array}$} & \multirow[t]{2}{*}{ Locality } & \multirow[t]{2}{*}{ SG } & \multicolumn{3}{|c|}{ Sample size (locality) } & \multirow[t]{2}{*}{ PD } & \multicolumn{3}{|c|}{ Sample size (PD) } \\
\hline & & & W & M & Total & & W & $M$ & Total \\
\hline Aplahoué & Badjamè & Adja & 9 & 11 & 20 & Zou & 51 & 46 & 97 \\
\hline Djidja & Sovlègni & Fon & 18 & 19 & 37 & & & & \\
\hline Dassa & Fita & Idatcha & 13 & 7 & 20 & & & & \\
\hline Savè & Akon & Tchabè & 11 & 9 & 20 & & & & \\
\hline Ouessè & Ikèmon & Nago & 9 & 11 & 20 & South Borgou & 31 & 29 & 60 \\
\hline Ouessè & Gbanlin & Mahi & 10 & 10 & 20 & & & & \\
\hline Ouessè & Idadjo & Nago & 12 & 8 & 20 & & & & \\
\hline Bantè & Banon & Itcha & 6 & 15 & 21 & Bassila & 26 & 35 & 61 \\
\hline Savalou & Obi-Coro & Ifè & 8 & 12 & 20 & & & & \\
\hline Bassila & Manigri & Tchabè & 12 & 8 & 20 & & & & \\
\hline Total & & & 108 & 110 & 218 & & 108 & 110 & 218 \\
\hline
\end{tabular}

SG sociolinguistic group, $W$ women, $M$ men, $P D$ phytodistrict 
listed by respondents were translated into a presence-absence matrix by phytodistrict and species accumulation curve was generated based on the first-order Jackknife method and 100 permutations, using EstimateS version 9.1.0 software for Macintosh [36]. The first-order Jackknife is a non-parametric incidence-based estimator that gives an accurate approximation of species richness [37]. Diversity of wild spices in each phytodistrict was assessed using Shannon's diversity index computed in EstimateS also using the species accumulation curve. To compare the estimated wild spices richness and diversity among phytodistricts, Kruskal-Wallis test was applied since assumptions of normality and homogeneity of variance were violated [38]. In addition, the Dunn post hoc test was performed. The Dunn post hoc test is appropriate for groups with unequal sizes [39]. Differences in wild spices composition among phytodistricts as cited by respondents were tested using analysis of similarities (ANOSIM) [40]. ANOSIM was based on Jaccard's dissimilarity distance using 1000 permutations. To describe probable relationship between the species and their habitats as locally mentioned, a correspondence analysis (CA) was performed on the contingency table with species in rows and habitats in columns.

Traditional knowledge was assessed through calculation of the use report (UR) [41] which is the number of uses reported by a given informant. Since the UR values were not over-dispersed, a generalized linear model (GLM) with Poisson error distribution was applied to assess their variation according to phytodistrict, sociolinguistic group, gender, age category, main activity, and education level. The model that best fits with the data was selected by combining Akaike information criteria (AIC) and Bayesian information criteria (BIC). To assess the homogeneity in the information provided by the respondents, the informant consensus factor $\left(F_{\text {ic }}\right)$ was calculated for each use category and across use categories, using the following formula [42]:

$$
F_{\mathrm{ic}}=\frac{n_{\mathrm{ur}}-n_{\mathrm{t}}}{n_{\mathrm{ur}}-1}
$$

Where:

$F_{\text {ic }}=$ informant consensus factor

$n_{\mathrm{ur}}=$ number of use reports from informants for a

particular plant use category

$n_{\mathrm{t}}=$ number of taxa that are used for that plant use

category for all informants.

$F_{\text {ic }}$ values range between 0 and 1 . Values close to 0 indicate that the plants are chosen randomly in the use category, or the informants do not exchange information about their use. High $F_{\text {ic }}$ values (near 1) indicate that the plants are chosen based on a well-defined criterion in the community and/or the information is shared among informants [43].
Cultural importance of the wild spices was assessed using the cultural importance value from both individual informant and community perspectives as in Paniagua Zambrana et al. [44]. The cultural importance value from individual informant perspective was calculated as follow [41]:

$$
\mathrm{CI}=\sum_{u=u_{1}}^{u_{\mathrm{NC}}} \sum_{i=i_{1}}^{i_{N}} \mathrm{UR}_{u i} / N
$$

where:

$\mathrm{UR}_{\mathrm{ui}}=$ total number of informants reporting a species

within a particular use category

$\mathrm{NC}=$ total number of use categories

$N=$ total number of informants.

Community cultural importance was calculated for each species following Paniagua Zambrana et al. [44] as the sum across all use categories of the number of communities reporting the species divided by the total number of communities surveyed.

To assess the importance of each wild spice, the use value (UV) index modified by Rossato et al. [45] from Phillips and Gentry [46] as follow:

$$
U V=\sum U / n,
$$

where:

$$
\begin{aligned}
& U V=\text { use value of a species } \\
& U=\text { number of quotations per species } \\
& n=\text { number of informants. }
\end{aligned}
$$

For defining priority wild spices for conservation, the approach proposed by Magos Brehm et al. [21] and recently applied by Idohou et al. [47] to the Crop wild relatives in Benin was used. Eight criteria were used: (i) native status, (ii) economic value, (iii) ethnobotanical value, (iv) global distribution, (v) national distribution, (vi) in-situ and ex-situ conservation status, (vii) legislation, and (viii) threats assessment (IUCN redlist). The method consisted in combining four different prioritization setting methods that used the aforementioned criteria: Point Scoring Procedure (PSP), Point Scoring Procedure with Weighting (PSPW), Compound Ranking System (CRS), and Binomial Ranking System (BRS). In PSP, the inventoried species were given a series of scores for each criterion (Table 2). Then, the overall score was obtained for each wild spice by adding the scores of individual criteria. Species with a greater value have higher conservation needs. PSWP is comparable to PSP, except that here a specific weight was assigned to each criterion (Table 2). The CRS method is based on the individual criterion ranking positions, which were combined to 
Table 2 Score attribution in the point scoring procedure (PSP) and point scoring procedure with weighting (PSPW) (adapted from Magos Brehm et al. [21])

\begin{tabular}{|c|c|c|c|}
\hline Criteria & Evaluation criteria & Score attribution (PSP) & $\begin{array}{l}\text { PSPW } \\
\text { weight (\%) }\end{array}$ \\
\hline Species origin & (a) Native, (b) exotic, (c) doubtfully native, (d) no data & (a) 4; (b) 3; (c) 2; (d) 1 & 15 \\
\hline Economic value & (a) high, (b) average, (c) Low, (d) no data & (a) 4; (b) 3; (c) 2; (d) 1 & 10 \\
\hline Ethnobotanical value & $\begin{array}{l}\text { (a) 19-21; (b) 16-18; (c) 13-15; (d) 10-12; (e) 7-9; (f) 4-6; } \\
\text { (g) 1-3; (h) No known uses }\end{array}$ & (a) 7; (b) 6; (c) 5; (d) 4; (e) 3; (f) 2; (g) 1; (h) 0 & 20 \\
\hline Global distribution & $\begin{array}{l}\text { (a) WA, (b) WA }+1 \text { region, (c) WA }+2 \text { regions, (d) WA }+3 \\
\text { regions, (e) Africa, (f) worldwide, (g) no data }\end{array}$ & (a) 6; (b) 5; (c) 4; (d) 3; (e) 2; (f) 1; (g) 0 & 15 \\
\hline National distribution & $\begin{array}{l}\text { (a) 1; (b) 2; (c) 3; (d) 4; (e) 5; (f) 6; (g) 7; (h) 8; (i) 9; (j) } \\
\text { 10; (k) no data }\end{array}$ & $\begin{array}{l}\text { (a) } 10 ; \text { (b) } 9 ; \text { (c) } 8 \text {; (d) 7; (e) 6; (f) 5; (g) 4; (h) 3; } \\
\text { (i) 2; (j) } 1 ; \text { (k) } 0\end{array}$ & 7.5 \\
\hline Conservation status & (a) In situ, (b) ex-situ, (c) other, (d) no data & (a) 4; (b) 3; (c) 2; (d) 1 & 10 \\
\hline Legislation & (a) international, (b) national, (c) locale, (d) no data & (a) 4; (b) 3; (c) 2; (d) 1 & 7.5 \\
\hline Threatened status & (a) $C R$, (b) EN, (c) VU, (d) NT, (e) LC, (f) DD, (g) NE & (a) 7; (b) 6; (c) 5; (d) 4; (e) 3; (f) 2; (g) 1 & 15 \\
\hline
\end{tabular}

WA West Africa, $C R$ critically endangered, $E N$ endangered, $V U$ vulnerable, $N T$ near threatened, $L C$ least concern, $D D$ data deficient, $N E$ not evaluated

obtain a compound rank for each species (Table 3). BRS uses a series of questions with binomial answers (i.e., "yes" or "no"). The yes answer (1) was always given more priority than the no (0). A sub-list of eight priority wild spices was established for each method. The number of times that the same species appeared on each sub-list was marked, and each species was given an overall score. The five species that have received the greater overall scores were given higher priority. In the case where many species had the same overall score, cultural importance and socioeconomic considerations were used to separate the species.

All analyses were conducted in the statistical software $\mathrm{R}$ 3.4.1 [48]. The Dunn hoc test was performed using the package FSA [49], the ANOSIM analysis in the vegan package [50], and the correspondence analysis in the package FactomineR [51].

\section{Results}

\section{Diversity and richness of wild spices}

Estimation of wild spices richness indicated 14 species in the Sudanian zone (CI 13.83-14.32) belonging to 9 families and 12 genera (Table 4). The three most important families were Zingiberaceae (3 species), Annonaceae (3 species), and Rutaceae ( 2 species). The remaining 6 families (Lamiaceae, Poaceae, Verbenaceae, Piperaceae, Polygonaceae, and Balanophoraceae) were represented by only one species each. The species were composed of herbs (42.86\%), shrubs (28.37\%), trees (21.43\%), and liana (7.14\%).

Estimation of species richness by phytodistrict revealed 11 species (CI 10.78-11.54) belonging to 8 families in Zou, 5 species (CI 4.94-5.01) belonging to 4 families in Bassila, and 4 species (CI 3.93-4.05) belonging to 4 families in South-Borgou (Fig. 2). The first-order Jackknife estimator overestimated wild spices richness as the sampling started and then decreased slightly with increasing sample size (Fig. 3a). Comparison of estimated richness among phytodistricts indicated that wild spices richness was significantly higher in Zou than in Bassila and South-Borgou respectively (Fig. 3a; $p<0.001$ ). Similarly, the Shannon diversity index was significantly higher in Zou (1.58) than Bassila (1.43) and South-Borgou (1.22) respectively (Fig. $3 \mathrm{~b} ; p<0.001$ ). Therefore, the phytodistrict of Zou was the richest and most diversified in terms of used wild spices.

Table 3 Rank attribution in the compound ranking system (CRS) method (adapted from Magos Brehm et al. [21])

\begin{tabular}{|c|c|c|c|c|c|c|c|c|c|c|c|}
\hline \multirow[t]{2}{*}{ Criteria } & \multicolumn{11}{|c|}{ Rank of sub-criteria } \\
\hline & $\mathrm{R} 1$ & $\mathrm{R} 2$ & R3 & R4 & R5 & R6 & R7 & R8 & R9 & R10 & R11 \\
\hline Species origin & Native & Exotic & Doubtfully native & No data & - & - & - & - & - & - & - \\
\hline Economic value & High & Average & Low & No data & - & - & - & - & - & - & - \\
\hline Ethnobotanical value & 20 & 19 & 18 & 17 & 16 & 15 & 14 & 13 & 12 & No data & - \\
\hline Global distribution & WA & WA + 1 region & $W A+2$ regions & $W A+3$ regions & Africa & World & No data & - & - & - & - \\
\hline National distribution & 1 & 2 & 2 & 4 & 5 & 6 & 7 & 8 & 9 & 10 & No data \\
\hline Conservation status & in situ & ex situ & Other & No data & - & - & - & - & - & - & - \\
\hline Legislation & International & National & Local & No data & - & - & - & - & - & - & - \\
\hline Threatened status & $C R$ & EN & VU & NT & LC & DD & NE & - & - & - & - \\
\hline
\end{tabular}

WA West Africa, CR critically endangered, EN endangered, $V U$ vulnerable, NT near threatened, LC least concern, $D D$ data deficient, $N E$ not evaluated 
Table 4 General characteristics of the wild spices inventoried

\begin{tabular}{|c|c|c|c|c|c|c|c|c|c|c|}
\hline$N^{\circ}$ & Species & Family & $\begin{array}{l}\text { Vernacular name } \\
\text { (sociolinguistic group) }\end{array}$ & LF & PT & Habitat & PU & PA & Use categories & LF \\
\hline 1 & $\begin{array}{l}\text { Aeollanthus } \\
\text { pubescens Benth. }\end{array}$ & Lamiaceae & Fé okuta, Kpon'kouta (Tchabè) & $\mathrm{H}$ & S & 7 & $\begin{array}{l}\text { If, fw, } \\
\text { wp }\end{array}$ & RS & foo, med & $\mathrm{H}$ \\
\hline 2 & $\begin{array}{l}\text { Aframomum } \\
\text { alboviolaceum (Ridley) } \\
\text { K.Schum. }\end{array}$ & Zingiberaceae & $\begin{array}{l}\text { Gbétakin (Fon); Koutchou (Adja); Atalè } \\
\text { okou, Ibouro (Idatcha); Ebouro, Ibio, } \\
\text { Bobota (Ifè, Tchabè); Okpogloé (Mahi); } \\
\text { Ebo (Itcha) }\end{array}$ & $\mathrm{H}$ & AT & $\begin{array}{l}3,4,5 \\
6\end{array}$ & $\begin{array}{l}\text { If, rt., } \\
\text { st, fr, } \\
\text { sd }\end{array}$ & DS & $\begin{array}{l}\text { foo, med, } \\
\text { fod, oth }\end{array}$ & $\mathrm{H}$ \\
\hline 3 & $\begin{array}{l}\text { Aframomum angustifolium } \\
\text { (Sonn.) K.Schum. }\end{array}$ & Zingiberaceae & Tchankoko (Ifè, Tchabè) & $\mathrm{H}$ & GC & $3,4,6$ & $\begin{array}{l}\text { If, rt., } \\
\text { st, fr }\end{array}$ & RS & $\begin{array}{l}\text { foo, med, } \\
\text { cult, oth }\end{array}$ & $\mathrm{H}$ \\
\hline 4 & $\begin{array}{l}\text { Aframomum melegueta } \\
\text { (Roscoe) K.Schum. }\end{array}$ & Zingiberaceae & Takù (Adja) & $\mathrm{H}$ & GC & 5,6 & $\begin{array}{l}\text { If, rt., } \\
\text { sd }\end{array}$ & NA & med, cult & $\mathrm{H}$ \\
\hline 5 & $\begin{array}{l}\text { Clausena anisata (Willd.) } \\
\text { Hook.f. ex Benth. }\end{array}$ & Rutaceae & $\begin{array}{l}\text { Azizinma, Gbozohouin, Tchakatouma } \\
\text { (Fon); Ewé kikani (Idatcha) }\end{array}$ & Sh & SG & 3,7 & If, rt & RS & med, cult & S \\
\hline 6 & $\begin{array}{l}\text { Cymbopogon giganteus } \\
\text { (Hochst.) Chiov. }\end{array}$ & Poaceae & Oflin (Idatcha); gbézin (Fon) & $\mathrm{H}$ & AT & 3,7 & If & AS & $\begin{array}{l}\text { foo, med, } \\
\text { fod }\end{array}$ & $\mathrm{H}$ \\
\hline 7 & Lippia multiflora Moldenke & Verbenaceae & $\begin{array}{l}\text { Nyenya, aglàla (Fon, Mahi); Aglàla, } \\
\text { Aklala sê (Mahi); Kanhoun (Idatcha); } \\
\text { Tchagara (Ifè); Tchagà (Itcha); } \\
\text { Kinhoun kinhoun, Kanhoun } \\
\text { kanhoun (Tchabè) }\end{array}$ & Sh & S & $\begin{array}{l}1,2,3 \\
4,6,7\end{array}$ & $\begin{array}{l}\text { If, fw, } \\
\text { st, rt., } \\
\text { wp }\end{array}$ & AS & $\begin{array}{l}\text { foo, med, } \\
\text { cult }\end{array}$ & S \\
\hline 8 & Monodora tenuifolia Benth. & Annonaceae & Ariwo (Idatcha) & T & GC & 7 & $\begin{array}{l}\text { rt, bk, } \\
\text { sd }\end{array}$ & RS & $\begin{array}{l}\text { foo, med, } \\
\text { cult }\end{array}$ & $\mathrm{T}$ \\
\hline 9 & $\begin{array}{l}\text { Piper guineense Schumach. } \\
\text { \& Thonn. }\end{array}$ & Piperaceae & Kanlin man, lènlènkoun (Adja) & L & AT & 4,5 & $\begin{array}{l}\text { If, fr, st, } \\
\text { rt }\end{array}$ & AS & $\begin{array}{l}\text { foo, med, } \\
\text { cult }\end{array}$ & L \\
\hline 10 & $\begin{array}{l}\text { Securidaca longipedunculata } \\
\text { Fresen. }\end{array}$ & Polygonaceae & $\begin{array}{l}\text { Attakpa wanon, Attakpa wanhuin } \\
\text { huin, Kpatalè (Fon, Idatcha) }\end{array}$ & Sh & AT & $3,4,7$ & $r t, b k$ & AS & med & S \\
\hline 11 & Thonningia sanguinea Vahl & Balanophoraceae & Atin madodè (Idatcha); Otchoulélé (Ifè) & $\mathrm{H}$ & AT & $3,4,6$ & $\mathrm{rt}$ & RS & med & $\mathrm{H}$ \\
\hline 12 & Uvaria chamae P.Beauv. & Annonaceae & Yaha (Idatcha); Yalaha (Fon) & Sh & SGC & $3,4,7$ & If, fr, rt & AS & foo, med & S \\
\hline 13 & $\begin{array}{l}\text { Xylopia aethiopica (Dunal) } \\
\text { A.Rich. }\end{array}$ & Annonaceae & Esso (Adja) & T & AT & 5 & $\mathrm{fr}$ & AS & med, cult & T \\
\hline 14 & $\begin{array}{l}\text { Zanthoxylum zanthoxyloides } \\
\text { (Lam.) Zepernick \& Timler }\end{array}$ & Rutaceae & Tchanouwèlè (Itcha); Sanouyèlè (Tchabè) & $\mathrm{T}$ & SG & $\begin{array}{l}1,2,3 \\
4\end{array}$ & rt & AS & foo, med & $\mathrm{T}$ \\
\hline
\end{tabular}

LF life form, $P T$ phytogeographical type, $P A$ period of availability, $H$ herb, $L$ liana, Sh shrub, $T$ tree, $A T$ afrotropical, GC Guineo-Congolian, $S$ Sudanian, SG SudanoGuinean, SGC Sudano-Guineo-Congolian, If leaf, fw flower, wp whole plant, rt. root, st stem, sd seed, fr fruit, $b k$ bark, cer ceremony, med medicine, foo food, cult cultural, oth other, DS dry season, AS all season, RS rainy season, 1 home garden, 2 field, 3 savanna, 4 natural forest, 5 sacred forest, 6 wetland, 7 hill

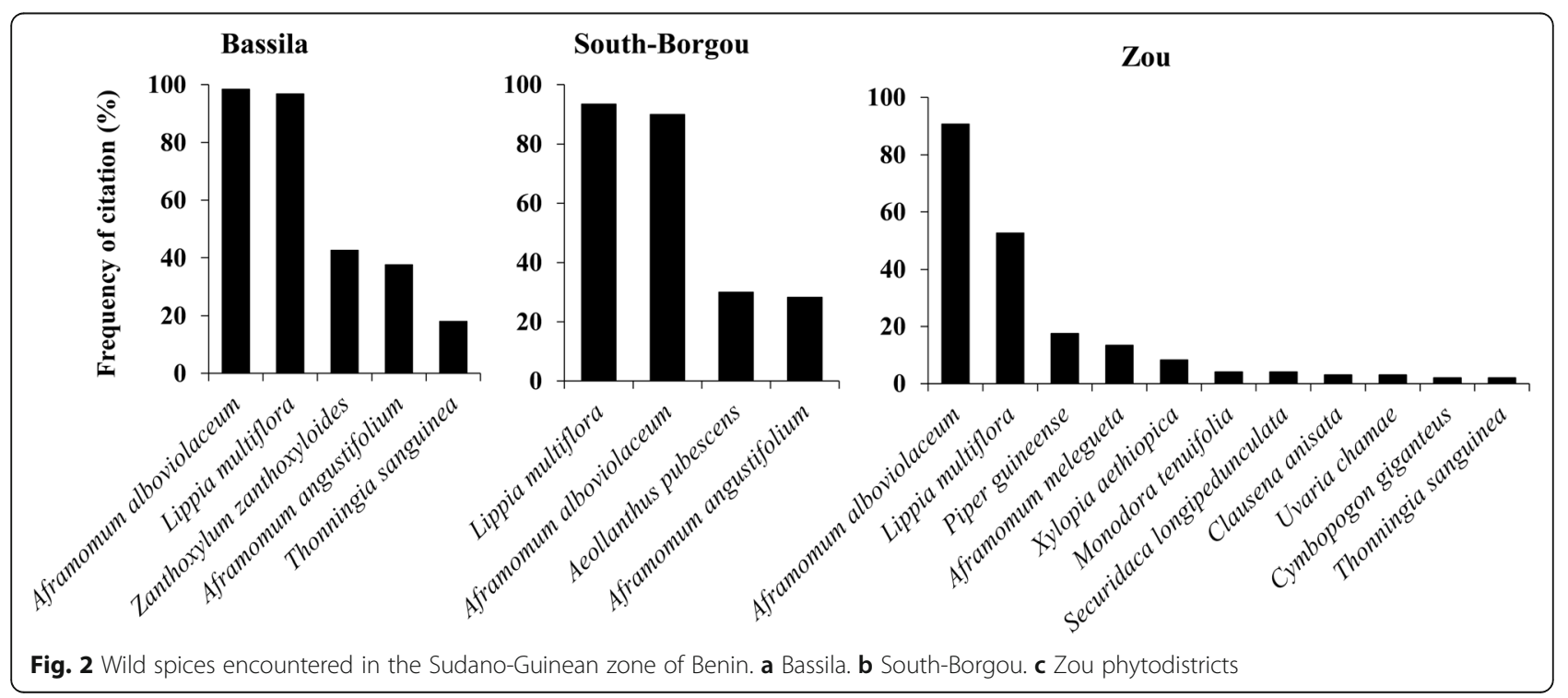



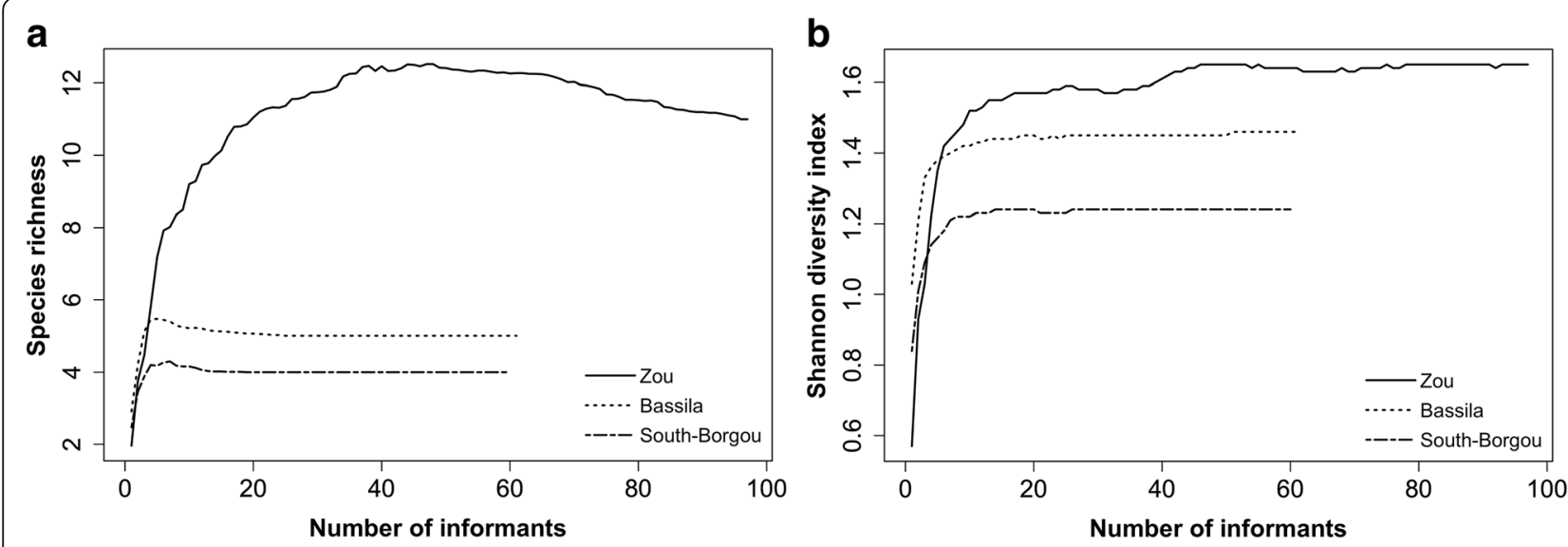

Fig. 3 Estimated species richness (a) and Shannon's diversity (b) for the species based on incidence data

There were significant differences in the composition of wild spices used by respondents among phytodistricts (ANOSIM; $R=0.123, p=0.001$ ). Coefficient of similarity between Zou and South-Borgou $(0.15, p=0.003)$ and the one between Zou and Bassila $(0.23, p \leq 0.001)$ were low. This reveals that the people in the phytodistricts of Zou knew and used wild spices differently from those of the people from South-Borgou and Bassila respectively. Conversely, the coefficient of similarity between Bassila and South-Borgou was $0.50(p \leq 0.001)$, indicating that half of the species mentioned as wild spices by people from Bassila were also known by informants from South-Borgou, and vice-versa.

The distribution of the spices according to their chorological type showed the predominance of Afrotropical (42.86\%) and Guineo-Congolian (21.43\%) species whereas Sudanian (14.29\%), Sudano-Guinean (14.29\%), and SudanoGuinean (7.13\%) elements were poorly represented (Table 4). Vernacular names were diverse and varied according to the species but also among areas as well as within the same sociolinguistic area (Table 4). Indeed, 42 vernacular names were recorded for the 14 investigated wild spices. The analysis of the meanings of vernacular names in each dialect (Table 5) revealed that the wild spices were named essentially based on their morphological traits, habitats, taste, habits, smell, or origin. However, for some species, the meanings of the vernacular names were unknown to local people. Occasionally, different sociolinguistic groups, often occupying the same geographical area share the same vernacular names for a given species. Pictures of selected wild spices are presented in Figs. 4 and 5.

\section{Local perception on the distributional pattern of species across habitat types}

Result of the CA performed on the wild spices and their habitats (with $82.62 \%$ of the observed variation saved on the first two axes) indicated that Xylopia aethiopica
(Dunal) A.Rich., Piper guineense Schumach. \& Thonn., and Aframomum melegueta (Roscoe) K.Schum. were mainly reported as occurring in sacred groves while Zanthoxylum zanthoxyloides (Lam.) Zepernick \& Timler, Lippia multiflora Moldenke, Aframomum angustifolium (Sonn.) K.Schum., Aframomum alboviolaceum (Ridley) K.Schum., Thonningia sanguinea Vahl, and Uvaria chamae P.Beauv. were reported to mainly occur in savanna, home gardens, fields, natural forests, or wetlands (axis 1; Fig. 6). Aeollanthus pubescens Benth., Monodora tenuifolia Benth., Clausena anisata (Willd.) Hook.f. ex Benth., Securidaca longipedunculata Fresen., and Cymbopogon giganteus (Hochst.) Chiov. were reported as occurring on rocky soils and hills (axis 2; Fig. 6).

\section{Traditional knowledge and cultural importance of the wild spices \\ Traditional knowledge (TK) on the wild spices}

Traditional knowledge (TK) on wild spices varied $(p<0.05)$ according to phytodistricts, sociolinguistic groups and gender. No variation $(p>0.05)$ of TK was observed with respect to age category, main activity, or education level. Informants reported the same number of uses of wild spices in both Bassila (UR $=4.59 \pm 0.22$ ) and South-Borgou ( $\mathrm{UR}=4.05 \pm 0.17$ ) phytodistricts while less uses were reported in Zou phytodistrict ( $\mathrm{UR}=3.13 \pm 0.18$ ). As regards variation according to the gender, men reported more uses than women $(U R=4.09 \pm 0.18$ and $U R=3.46 \pm 0.14$ respectively). For sociolinguistic group variation, Tchabè in Bassila held the highest level of traditional knowledge $(\mathrm{UR}=5.70 \pm 0.33)$ followed by Itcha $(\mathrm{UR}=4.38 \pm 0.40)$ and Ifè (UR $=3.70 \pm 0.24)$ sociolinguistic groups respectively. In South-Borgou phytodistrict, the Nago reported more uses (UR $=4.13 \pm 0.23$ ) than the Mahi people $(U R=3.75 \pm 0.19)$. In Zou phytodistrict, the Idatcha reported more uses $(U R=4.62 \pm 0.59)$ than the other groups. The number of use reports was similarly 
Table 5 List of vernacular names recorded per species and their meaning

\begin{tabular}{|c|c|c|c|}
\hline Species & Vernacular names & Sociolinguistic groups & Meaning of the vernacular names \\
\hline Aeollanthus pubescens & Fé okuta, Kpon'kouta & Tchabè & Grow on the hills \\
\hline \multirow[t]{11}{*}{ Aframomum alboviolaceum } & Gbétakin & Fon & Bush pepper \\
\hline & Gbétakoun & Fon & Aframomum melegueta of the bush \\
\hline & Koutchou & Adja & - \\
\hline & \multirow[t]{2}{*}{ Atalè okou } & Idatcha & Bush pepper \\
\hline & & Ibouro & - \\
\hline & Ebouro & Ifè & Red fruit \\
\hline & Ibio & Nago & Red fruit \\
\hline & \multirow[t]{2}{*}{ Bobota } & \multirow[t]{2}{*}{ Tchabè } & Red fruit emerging from the ground \\
\hline & & & Pungent seeds like $A$. melegueta's ones \\
\hline & Okpogloé & Mahi & Fruits emerging from the ground \\
\hline & Ebo & Itcha & Red fruit \\
\hline \multirow[t]{2}{*}{ Aframomum angustifolium } & Tchankoko & \multirow[t]{2}{*}{ Ifè, Nago Tchabè, } & - \\
\hline & Sankoko & & - \\
\hline Aframomum melegueta & Takù & Adja & - \\
\hline \multirow[t]{4}{*}{ Clausena anisata } & Azizinma & Fon & Repel the ants \\
\hline & Tchakatouma & Fon & $\begin{array}{l}\text { Leaves used for making magic to counter } \\
\text { tchakatou dark magic }\end{array}$ \\
\hline & Gbozohouin & Fon & - \\
\hline & Ewé kikani & Idatcha & - \\
\hline \multirow[t]{2}{*}{ Cymbopogon giganteus } & Oflin & Idatcha & - \\
\hline & Gbézin & Fon & - \\
\hline \multirow[t]{8}{*}{ Lippia multiflora } & Nyenya & Fon & - \\
\hline & Aglàla & Fon, Mahi & - \\
\hline & Aklala sê & Mahi & $\begin{array}{l}\text { Plant with aromatic flower introduced from } \\
\text { Accra (Ghana) }\end{array}$ \\
\hline & Kanhoun & Idatcha & - \\
\hline & Tchagara & Ifè & Mint flavor \\
\hline & Tchagà & Itcha & - \\
\hline & Kinhoun kinhoun & Nago & Pleasant flavor \\
\hline & Kanhoun kanhoun & Tchabè & Pleasant flavor \\
\hline Monodora tenuifolia & Ariwo & Idatcha & - \\
\hline \multirow[t]{2}{*}{ Piper guineense } & Kanlin man & Adja & Liana habit \\
\hline & lènlènkoun & Adja & - \\
\hline \multirow[t]{2}{*}{ Securidaca longipedunculata } & Attakpa wanon, Attakpa wanhuin huin & Fon & Persistent scent of the root's bark \\
\hline & Kpatalè & Idatcha & - \\
\hline \multirow[t]{2}{*}{ Thonningia sanguinea } & Atin madodè & Idatcha & Leafless plant \\
\hline & Otchoulélé & Ifè & The flowers appear with the new moon \\
\hline \multirow[t]{2}{*}{ Uvaria chamae } & Yaha & Idatcha & - \\
\hline & Yalaha & Fon & \\
\hline Xylopia aethiopica & Esso & Adja & - \\
\hline \multirow[t]{2}{*}{ Zanthoxylum zanthoxyloides } & Tchanouwèlè & Itcha & Pungent taste and pleasant flavor \\
\hline & Sanouyèlè & Tchabè & Pungent taste and pleasant flavor \\
\hline
\end{tabular}



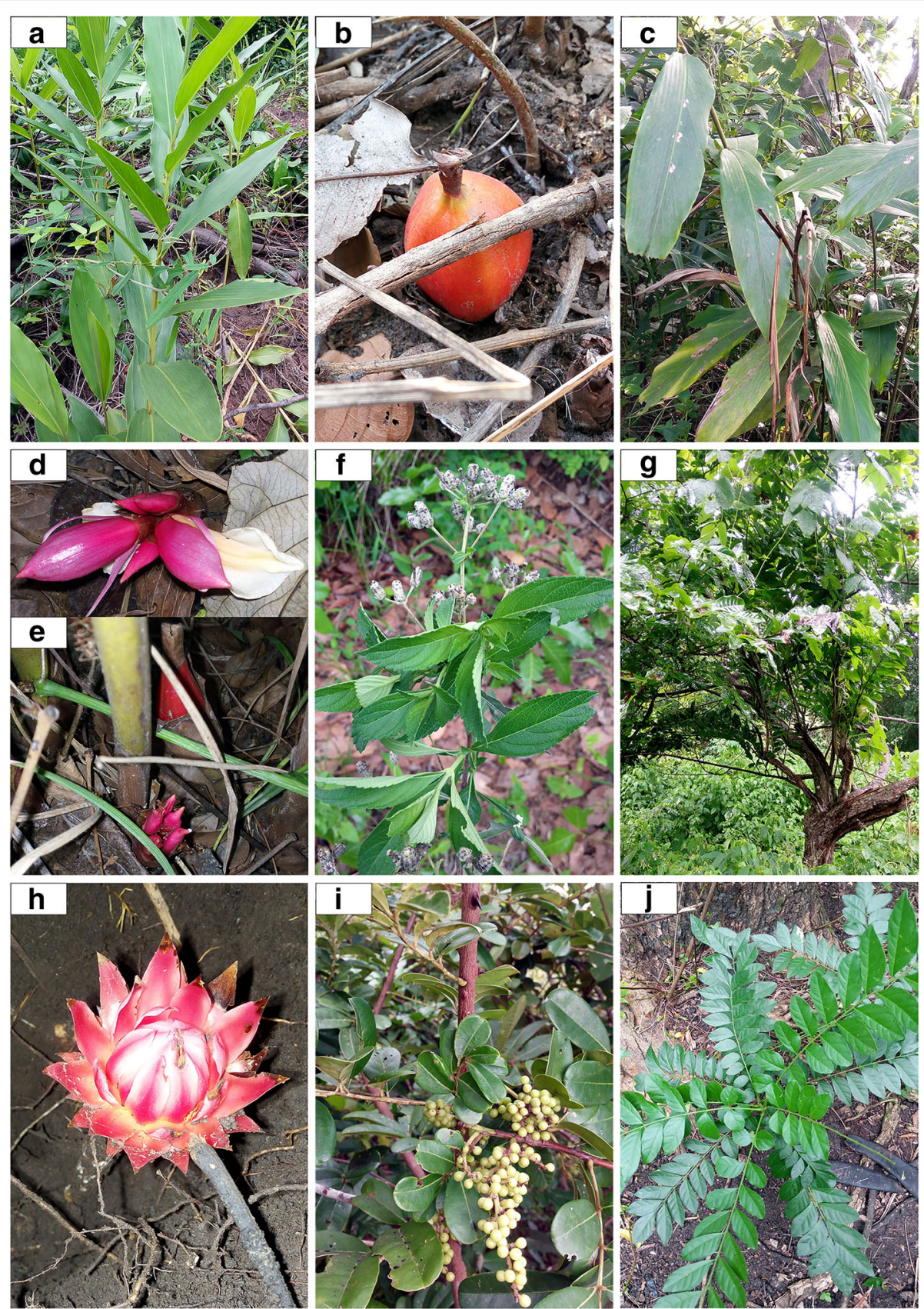

Fig. 4 Pictures of selected wild spices in the Sudano-Guinean zone of Benin. a Leaves and $\mathbf{b}$ fruit of Aframomum alboviolaceum. $\mathbf{c}$ Leaves, $\mathbf{d}$ flower, and $\mathbf{e}$ fruit of Aframomum angustifolium. $\mathbf{f}$ Leaves and flowers of Lippia multiflora. $\mathbf{g}$ Tree Monodora tenuifolia. $\mathbf{h}$ Flower of Thonningia sanguinea. $\mathbf{i}$ Leaves and unripe fruits of Zanthoxylum zanthoxyloides. $\mathbf{j}$ Leaves of Clausena anisata

low for the Adja, Fon, and Tchabè sociolinguistic groups (UR values of $3.04 \pm 0.40,2.69 \pm 0.29$, and $3.06 \pm 0.21$ respectively).

\section{Informants consensus factors ( $\left.F_{i c}\right)$ among and across use categories}

Overall, a great consistency was observed among the informants regarding the uses of the wild spices, with
$F_{\text {ic }}$ values varying from 0.72 to 0.98 (Table 6). Food use category had the highest $F_{\text {ic }}$ value 0.98 with 434 use reports for 10 plant species. The species responsible for this high value were Aframomum alboviolaceum and Lippia multiflora with 201 (24.78\%) and 151 (18.62\%) reported uses respectively. This category of use was followed by medicine ( $F_{\mathrm{ic}}=0.96 ; 304$ use reports, 14 species), culture ( $F_{\mathrm{ic}}=0.95 ; 21$ use reports, 2 species $)$, 

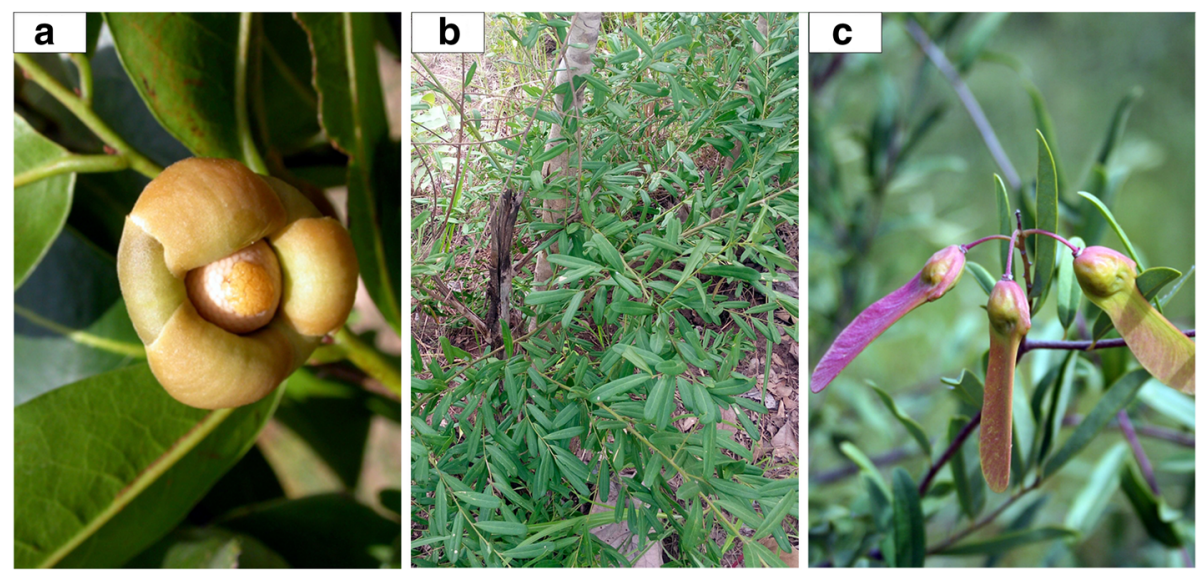

Fig. 5 Pictures of selected wild spices in the Sudano-Guinean zone of Benin. a Flower of Uvaria chamae. $\mathbf{b}$ Leaves and $\mathbf{c}$ fruits of Securidaca longipedunculata

and other uses $\left(F_{\mathrm{ic}}=0.84 ; 26\right.$ use reports, 5 species $)$. Other uses included food wrapping, fodder, rope for binding luggage in the field, and whip for punishing children. Similarly, the species responsible of the high number of reported uses within medicinal category were L. multiflora with 137 out of the 304 medicinal use reports (45.07\%) and A. alboviolaceum with 57 use reports $(18.75 \%)$. The least agreement between informants $\left(F_{\mathrm{ic}}=0.72 ; 26\right.$ use reports, 8 species $)$ was found for wild spices used for ceremony (Table 6). As regards the informants' consensus across the use categories, high degree of agreement $\left(F_{\mathrm{ic}}\right.$ ranged from 0.97 to 0.99 ) was observed across the phytodistricts (Table 7). A similar trend was found between gender with $F_{\text {ic }}=0.97$ for both women and men. As for the sociolinguistic groups, the highest agreement $\left(F_{\mathrm{ic}}=0.98\right)$ among information given by the informants was found for Nago and Tchabè people from Zou phytodistrict (Table 7). The least agreement $\left(F_{\mathrm{ic}}=0.88\right)$ was found for Idatcha sociolinguistic group.

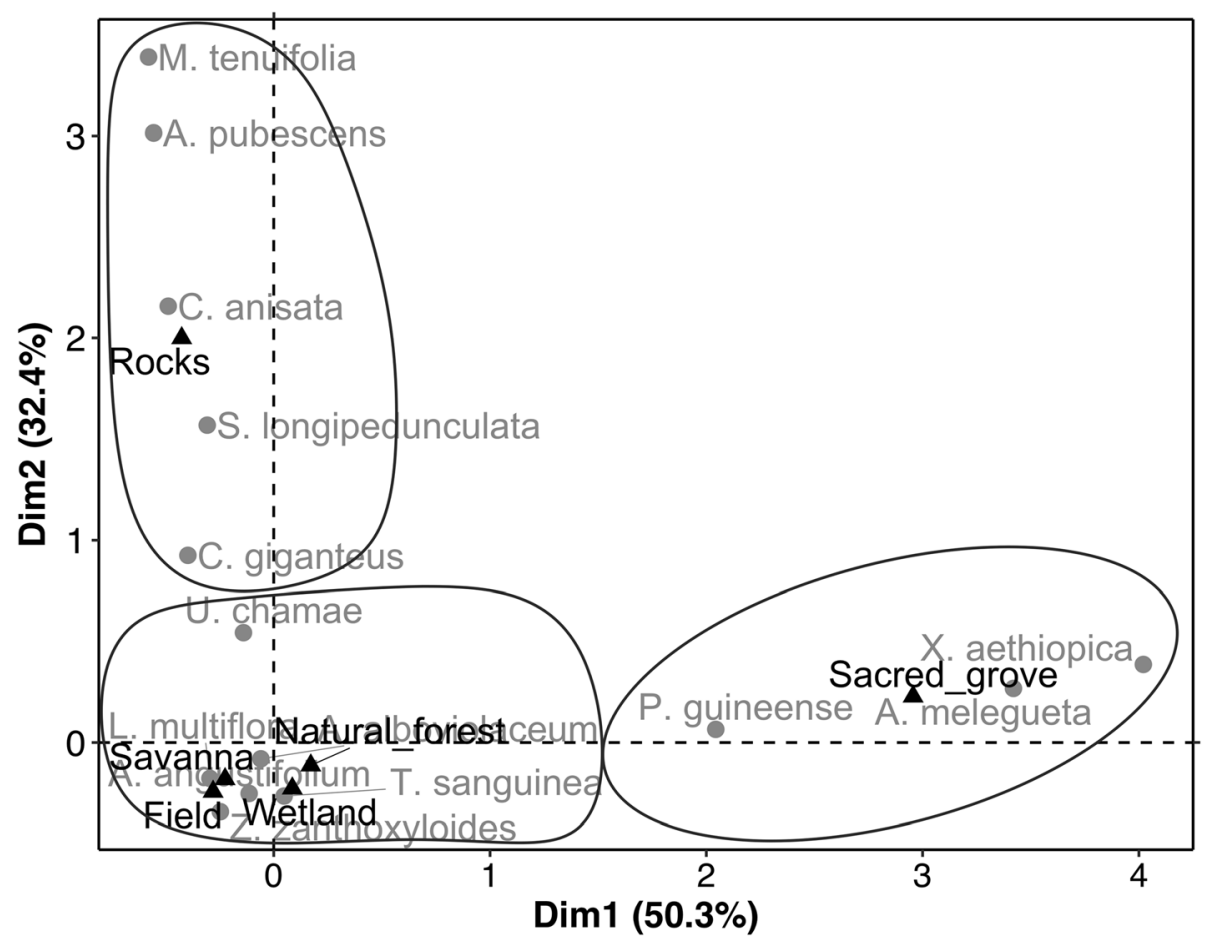

Fig. 6 Projection of the species and types of habitat in the correspondence analysis axes systems 
Table 6 Informant consensus factor $\left(F_{\mathrm{ic}}\right)$ by use category

\begin{tabular}{llllll}
\hline Use categories & $n_{\mathrm{ur}}$ & $\% \mathrm{ur}$ & $n_{\mathrm{t}}$ & $\%$ taxa & $F_{\mathrm{ic}}{ }^{*}$ \\
\hline Food & 434 & 53.45 & 10 & 71.43 & 0.98 \\
Medicine & 304 & 37.44 & 14 & 100.00 & 0.96 \\
Cultural & 21 & 2.59 & 2 & 14.29 & 0.95 \\
Ceremony & 26 & 3.20 & 8 & 57.14 & 0.72 \\
Other uses & 26 & 3.20 & 5 & 35.71 & 0.84 \\
Total & 811 & 99.88 & $14^{*}$ & $100.00^{*}$ &
\end{tabular}

$n_{u r}$ number of use report, ur use report, $n_{t}$ number of taxa, $F_{i c}$ informant consensus factor

*A taxon may be listed in many of the categories of use

\#A high Fic value indicates a high level of agreement among the informants regarding wild spices used for the corresponding use category; a low value indicates a low degree of agreement

\section{Cultural importance $(\mathrm{Cl})$ of the wild spices}

Based on the cultural importance index at informant level, the most culturally important wild spices in Bassila phytodistrict were L. multiflora $(\mathrm{CI}=1.67)$, A alboviolaceum $(\mathrm{CI}=1.38), Z$. zanthoxyloides $(\mathrm{CI}=0.85)$, and $A$. angustifolium $(\mathrm{CI}=0.51)$. In South-Borgou, L. multiflora $(\mathrm{CI}=2.07)$ and $A$. alboviolaceum $(\mathrm{CI}=1.30)$ were identified whereas $A$. alboviolaceum $(\mathrm{CI}=1.22)$ and $L$. multiflora $(\mathrm{CI}=0.87)$ were identified for Zou phytodistrict (Fig. 7). Therefore, people valued almost the same wild spices in all the Sudano-Guinean zone except in Bassila

Table 7 Informant consensus factor (Fic) across use categories

\begin{tabular}{lcccccc}
\hline \multicolumn{1}{c}{$n_{\text {ur }}{ }^{*}$} & $\%$ ur & $N$ & $n_{\mathrm{t}}$ & $\%$ taxa & $F_{\mathrm{ic}}{ }^{*}$ \\
\hline Phytodistrict & & & & & & \\
Bassila & 280 & 34.57 & 61 & 5 & 35.71 & 0.99 \\
South-Borgou & 239 & 29.51 & 60 & 4 & 28.57 & 0.99 \\
Zou & 291 & 35.93 & 97 & 11 & 78.57 & 0.97 \\
Sex & & & & & & \\
Men & 478 & 59.01 & 110 & 14 & 100 & 0.97 \\
Women & 332 & 40.99 & 108 & 12 & 85.71 & 0.97 \\
Sociolinguistic group & & & & & & \\
Adja & 70 & 8.64 & 20 & 4 & 28.57 & 0.96 \\
Fon & 94 & 11.6 & 37 & 8 & 57.14 & 0.92 \\
Idatcha & 60 & 7.41 & 20 & 8 & 57.14 & 0.88 \\
Ifè & 74 & 9.14 & 20 & 4 & 28.57 & 0.96 \\
Itcha & 92 & 11.36 & 21 & 4 & 28.57 & 0.97 \\
Mahi & 90 & 11.11 & 20 & 4 & 28.57 & 0.97 \\
Nago & 161 & 19.88 & 40 & 4 & 28.57 & 0.98 \\
Tchabè 1 & 55 & 6.79 & 20 & 2 & 14.29 & 0.98 \\
Tchabè 2 & 114 & 14.07 & 20 & 4 & 28.57 & 0.97 \\
\hline
\end{tabular}

$n_{u r}$ number of use report, ur use report, $N$ number of informants, $n_{t}$ number of taxa, $F_{i c}$ informant consensus factor

*A taxon may be listed in several categories of use

${ }^{\# A}$ high Fic value indicates a high level of agreement among the informants regarding wild spices used for the corresponding use category; a low value indicates a low degree of agreement where two species (Z. zanthoxyloides and A. angustifolium) were valued in addition. The most relevant categories of use were food followed by medicine for the three phytodistricts (Table 8).

L. multiflora was the common most culturally important wild spice for Mahi $(\mathrm{CI}=3.20)$, Tchabè from both Bassila $(\mathrm{CI}=1.90)$ and Zou $(\mathrm{CI}=1.50)$ phytodistricts, Nago $(C I=1.66)$, Itcha $(C I=1.57)$, Ifè $(C I=1.55)$, and Idatcha $(\mathrm{CI}=0.95)$ sociolinguistic groups, while it had relatively less importance for Fon $(\mathrm{CI}=0.78)$ and absolutely no importance for Adja. Similarly, A. alboviolaceum was highly valued by all sociolinguistic groups. $Z$. zanthoxyloides was most importantly valued by Tchabè from Bassila phytodistrict $(\mathrm{CI}=1.90)$ and lesser by Itcha $(\mathrm{CI}=0.66)$. P. guineense and A. melegueta were valued only by Adja ( $\mathrm{CI}=1.10$ and 0.80 respectively), whereas $M$. tenuifolia had cultural importance only for Idatcha $(\mathrm{CI}=0.50)$, and $A$. angustifolium for Itcha $(\mathrm{CI}=0.81)$ and Tchabè informants from Bassila phytodistrict ( $\mathrm{CI}=0.60$; Table 9).

Figure 8 shows that all the sociolinguistic groups valued food and medicinal uses for the wild spices. In addition, Mahi people also made cultural use of spices $(\mathrm{CI}=0.25)$ while Adja used them for ceremony $(\mathrm{CI}=0.19)$ and Ifè used them for other purposes $(\mathrm{CI}=0.09)$. Overall, wild spices were used for other purposes much less frequently. The most culturally important wild spices for both women and men were L. multiflora $(\mathrm{CI}=1.41$ and 1.44 for women and men respectively) and $A$. alboviolaceum $(\mathrm{CI}=1.07$ for women and $\mathrm{CI}=1.49$ for men). However, in comparison, men valued the wild spices more than women in an overall sense, as well as in medicine, for cultural, and other uses. By contrast, women informants used the wild spices for food purposes much more than men (Fig. 9).

Cultural importance index calculated at community and informant levels yielded different wild spices as of higher cultural significance. The most culturally important species in the surveyed communities were, in order of importance, A. alboviolaceum, L. multiflora, A. angustifolium, and P. guineense (Table 10). At informants' level and irrespective of sociolinguistic group, gender and phytodistrict, L. multiflora, A. alboviolaceum, and $Z$. zanthoxyloides had the greater cultural importance. Therefore, A. alboviolaceum and L. multiflora appeared as the most important wild spices for the surveyed communities (CIcom $=3.00$ and 2.10 respectively) and informants $($ Clinf $=1.28$ and 1.42 respectively; Table 10$)$.

\section{Use values of the wild spices (UV)}

The highest use value was reported for Aframomum alboviolaceum (UV=0.93; Table 11). Fifty-three specific uses were documented for this species of which the most important was the consumption of the fresh fruit flesh 


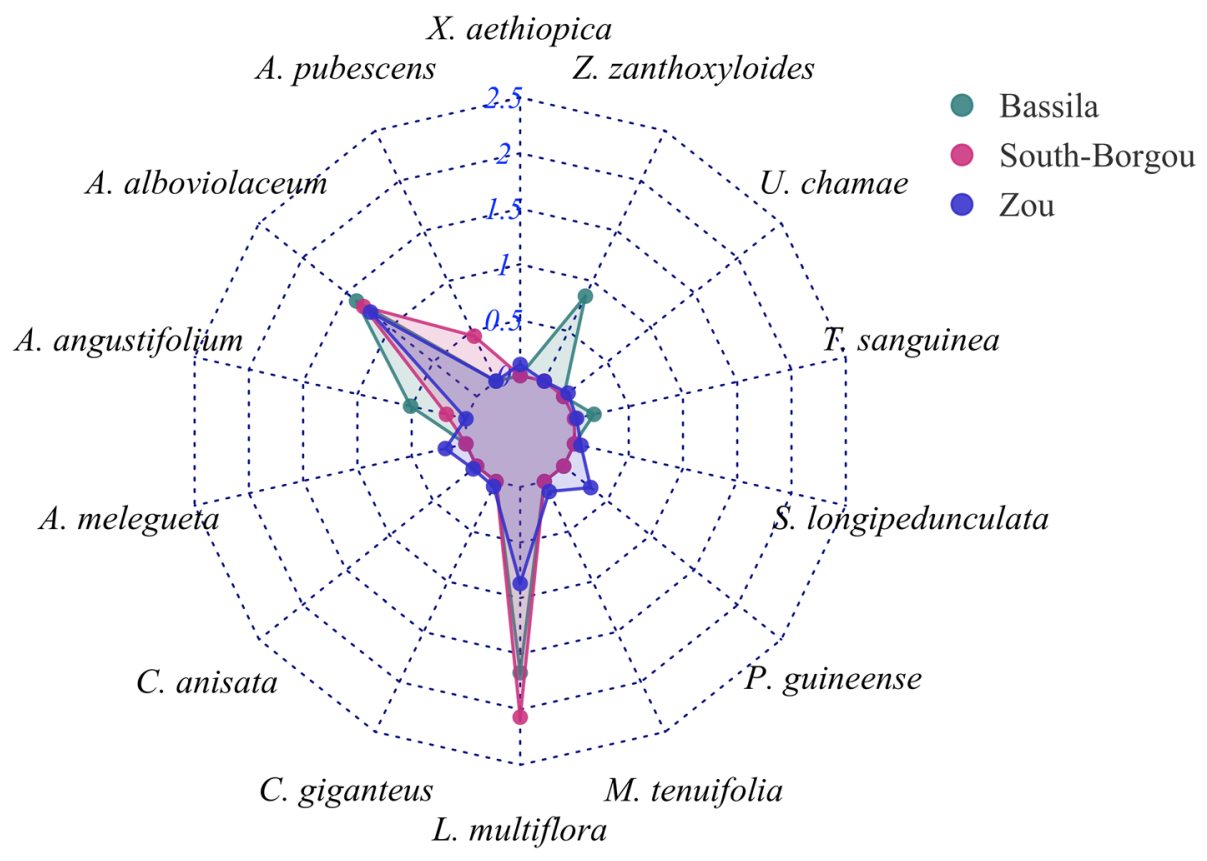

Fig. 7 Radar plot of total Cl value for each wild spice according to the phytodistrict

by rural people (Table 12). Lippia multiflora had the second highest use value ( $U V=0.76)$. The fresh young leaves constituted a well-appreciated aromatic spice across all the three phytodistricts. Leaves or inflorescences were often dried and crushed with condiments and served as seasoning in sauce. This spice was attributed stimulating effects on milk production for nursing women. L. multiflora was also particularly used for healing gastrointestinal ailments including indigestion, constipation, stomach-ache, dysentery, hemorrhoid, diarrhea, nausea, and vomiting. It is also said to have a great potential in regulating high blood pressure (Table 12). The species with the third highest use value was Aframomum angustifolium (UV=0.18). The species was cited only in Bassila and South-Borgou phytodistricts. Its crushed or pounded fresh roots were used to relief

Table 8 Cultural importance index (Cl, informant based) of wild spice use categories by phytodistrict

\begin{tabular}{llll}
\hline Use & & & \\
\cline { 2 - 4 } category & Bassila & South-Borgou & Zou \\
\hline Food & 0.52 & 0.52 & 0.14 \\
Medicine & 0.37 & 0.35 & 0.10 \\
Cultural & 0.00 & 0.09 & 0.00 \\
Ceremony & 0.01 & 0.00 & 0.02 \\
Other use & 0.02 & 0.04 & 0.01 \\
Total Cl & 0.92 & 1.00 & 0.27 \\
\hline
\end{tabular}

*Average number of wild spices inventoried in each phytodistrict: 5 in Bassila, 4 in South-Borgou, and 11 in Zou headache (Table 12). The fruit flesh was also eaten as for A. alboviolaceum.

\section{Uses diversity}

A total of 205 specific uses were recorded for the 14 wild spices in the three phytodistricts. The first three species with the highest specific uses were A. alboviolaceum (53 uses), followed by L. multiflora (45 uses) and A. angustifolium (29 uses), while only one specific use was mentioned for Cymbopogon giganteus. Wild spices were used mostly for medicine (144 uses) and lesser for cultural (1 use) purposes. All uses are documented in Table 12. Leaves had the highest number (64 uses) of specific uses while the bark ( 2 uses) had the lowest specific uses (Fig. 10).

\section{Local perception of the dynamic of wild spices populations and threatening factors}

Most of the informants (92.02\%) indicated their perception regarding the dynamic of wild spices' populations. Perceptions varied significantly among phytodistricts $(p<0.001)$, with no variation as regards age categories $(p=0.063)$ and gender $(p=0.131)$. Most respondents indicated that wild spices' populations declined over time. Stability was mentioned mostly in the phytodistrict of Zou; meanwhile, an increase was mentioned mainly in Bassila. No increase in the dynamic was recorded in the South-Borgou phytodistrict (Fig. 11). 
Table 9 Cultural importance index (informant based) of each species according to the different sociolinguistic groups

\begin{tabular}{llllllllll}
\hline Species & \multicolumn{3}{l}{ Sociolinguistic group } & & & & \\
\cline { 2 - 9 } & Adja & Fon & Idatcha & Ifè & Itcha & Mahi & Nago & Tchabè1 & Tchabè2 \\
\hline Aeollanthus pubescens & 0.00 & 0.00 & 0.00 & 0.00 & 0.00 & 0.00 & 0.68 & 0.00 & 0.00 \\
Aframomum alboviolaceum & 1.10 & 1.35 & 0.85 & 1.50 & 1.33 & 1.20 & 1.47 & 1.25 & 1.30 \\
Aframomum angustifolium & 0.00 & 0.00 & 0.00 & 0.10 & 0.81 & 0.00 & 0.29 & 0.00 & 0.60 \\
Aframomum melegueta & 0.80 & 0.06 & 0.00 & 0.00 & 0.00 & 0.00 & 0.00 & 0.00 & 0.00 \\
Clausena anisata & 0.00 & 0.06 & 0.10 & 0.00 & 0.00 & 0.00 & 0.00 & 0.00 & 0.00 \\
Cymbopogon giganteus & 0.00 & 0.00 & 0.25 & 0.00 & 0.00 & 0.00 & 0.00 & 0.00 & 0.00 \\
Lippia multiflora & 0.00 & 0.78 & 0.95 & 1.55 & 1.57 & 3.20 & 1.66 & 1.50 & 1.90 \\
Monodora tenuifolia & 0.00 & 0.00 & 0.50 & 0.00 & 0.00 & 0.00 & 0.00 & 0.00 & 0.00 \\
Piper guineense & 1.10 & 0.16 & 0.00 & 0.00 & 0.00 & 0.10 & 0.00 & 0.00 & 0.00 \\
Securidaca longipedunculata & 0.00 & 0.03 & 0.25 & 0.00 & 0.00 & 0.00 & 0.00 & 0.00 & 0.00 \\
Thonningia sanguinea & 0.00 & 0.03 & 0.05 & 0.55 & 0.00 & 0.00 & 0.00 & 0.00 & 0.00 \\
Uvaria chamae & 0.00 & 0.08 & 0.10 & 0.00 & 0.00 & 0.00 & 0.00 & 0.00 & 0.00 \\
Xylopia aethiopica & 0.50 & 0.00 & 0.00 & 0.00 & 0.00 & 0.00 & 0.00 & 0.00 & 0.00 \\
Zanthoxylum zanthoxyloides & 0.00 & 0.00 & 0.00 & 0.00 & 0.66 & 0.00 & 0.00 & 0.00
\end{tabular}

The main threatening factors purported responsible for the decline in wild spices' populations were agriculture, grazing, and drought in the three regions (Fig. 12). The most important factor was agriculture in SouthBorgou (cited by $33.33 \%$ of respondents), grazing in Zou (32.94\%), whereas drought and agriculture were equally quoted in Bassila (25.33\% each). Bushfires, demographic pressure, and charcoal production also contributed to a lesser extent to the decline of the spices population in the Zou, South-Borgou, and Bassila phytodistricts respectively.

Local perception of the nutritional value of the wild spices

Overall, $87.32 \%$ of informants indicated their perception of the nutritional value of the wild spices that they use in their diet. Significant variation of perceptions exists among phytodistricts $(p<0.001)$ and age categories $(p=0.038)$. However, no significant variation was observed between

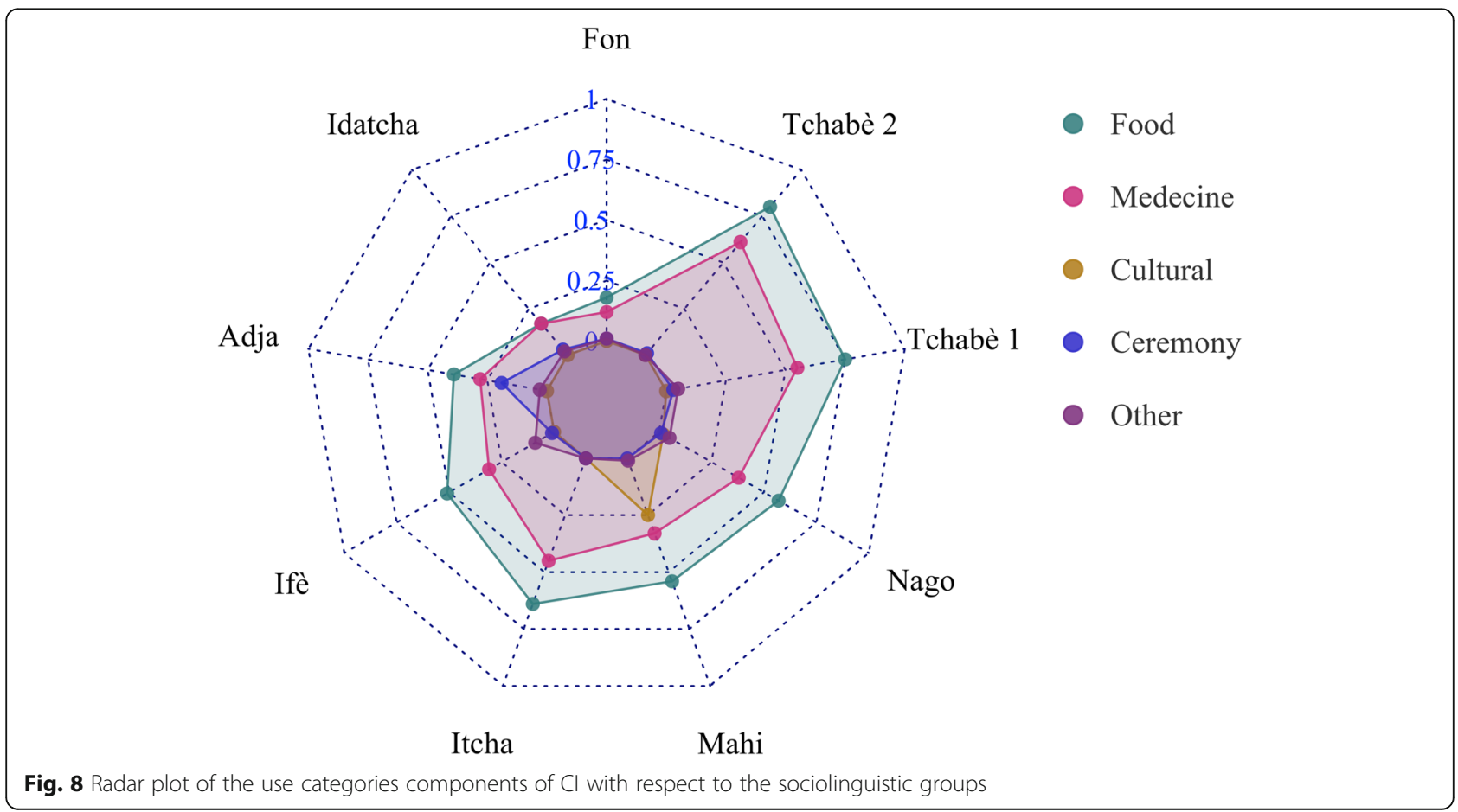




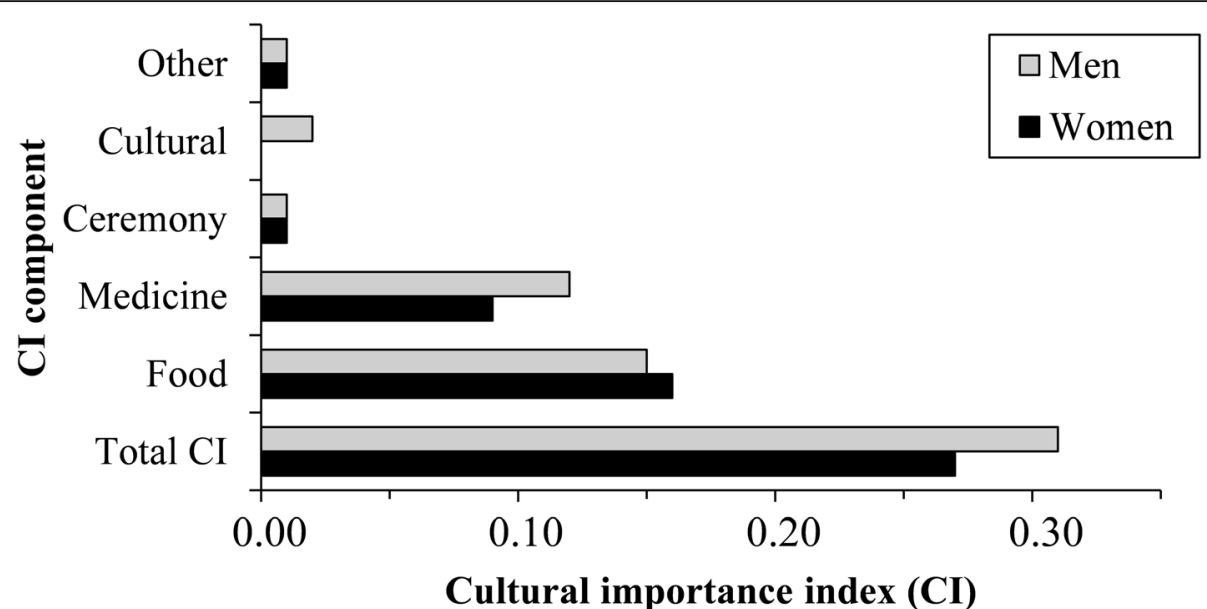

Fig. 9 Cultural importance index $(\mathrm{Cl})$ of the species by gender, with the $\mathrm{Cl}$ component of each use category

gender $(p=0.219)$. High nutritional value was mentioned mostly in South-Borgou and Bassila phytodistricts (respectively $71.93 \%$ and $57.89 \%$ of the respondents) whereas people from Zou (38.89\% of respondents) assigned an average nutritional value to the wild spices. Adults (62.34\%) and old informants (60\%) acknowledged higher nutritious value to wild spices compared to young (40.51\%). Overall, women and men perceived wild spices as highly nutritious (Fig. 13).

\section{Priority wild spices for conservation}

The Point Scoring Procedure (PSP) method yielded a list of priority wild spices for conservation, with $M$.

Table 10 Community and informant cultural importance of the inventoried 14 wild spices

\begin{tabular}{lll}
\hline Species & Clcom & Clinf \\
\hline Aeollanthus pubescens & 0.40 & 0.12 \\
Aframomum alboviolaceum & 3.00 & 1.28 \\
Aframomum angustifolium & 0.90 & 0.19 \\
Aframomum melegueta & 0.40 & 0.08 \\
Clausena anisata & 0.20 & 0.02 \\
Cymbopogon giganteus & 0.30 & 0.02 \\
Lippia multiflora & 2.10 & 1.42 \\
Monodora tenuifolia & 0.30 & 0.05 \\
Piper guineense & 0.60 & 0.14 \\
Securidaca longipedunculata & 0.30 & 0.03 \\
Thonningia sanguinea & 0.20 & 0.06 \\
Uvaria chamae & 0.20 & 0.02 \\
Xylopia aethiopica & 0.20 & 0.05 \\
Zanthoxylum zanthoxyloides & 0.50 & 0.24 \\
\hline
\end{tabular}

Most important species in each index are in italics

Clcom community cultural importance, Clinf informant cultural tenuifolia, L. multiflora, X. aethiopica, S. longipedunculata, and $A$. melegueta as top five highest priority. For the PSPW method, M. tenuifolia, X. aethiopica, L. multiflora, Z. zanthoxyloides, and S. longipedunculata appeared as the top five highest priority. For the CRS method, the top five priority wild spices were $M$. tenuifolia, $X$. aethiopica, L. multiflora, A. melegueta, Z. zanthoxyloides, and A. angustifolium. For the BRS method, the top five priority species were $A$. melegueta, $M$. tenuifolia, $P$. guineense, $U$. chamae, and $X$. aethiopica. By crossing results of each method, the top five species for conservation, selected in the Sudano-Guinean zone, were $A$. alboviolaceum, $L$. multiflora, $X$. aethiopica, Z. zanthoxyloides, and M. tenuifolia (Table 13).

Table 11 Use values of the wild spice species inventoried in the Sudano-Guinean zone of Benin

\begin{tabular}{lll}
\hline Species & $\Sigma \mathrm{U}$ & UV \\
\hline Aeollanthus pubescens & 18 & 0.08 \\
Aframomum alboviolaceum & 202 & 0.93 \\
Aframomum angustifolium & 40 & 0.18 \\
Aframomum melegueta & 13 & 0.06 \\
Clausena anisata & 3 & 0.01 \\
Cymbopogon giganteus & 2 & 0.01 \\
Lippia multiflora & 166 & 0.76 \\
Monodora tenuifolia & 4 & 0.02 \\
Piper guineense & 17 & 0.08 \\
Securidaca longepedunculata & 4 & 0.02 \\
Thonningia sanguinea & 13 & 0.06 \\
Uvaria chamae & 3 & 0.01 \\
Xylopia aethiopica & 8 & 0.04 \\
Zanthoxylum zanthoxyloides & 26 & 0.12 \\
\hline
\end{tabular}

$U$ number of quotations for a given species, UV use value 
Table 12 List of wild spices, used part, processing methods, and forms and purpose of use

\begin{tabular}{|c|c|c|c|c|c|c|c|}
\hline \multirow[t]{2}{*}{ Use category } & \multirow[t]{2}{*}{ Plant part } & \multirow[t]{2}{*}{ Processing method } & \multirow[t]{2}{*}{ Form of use } & \multirow[t]{2}{*}{ Purpose of use } & \multicolumn{3}{|c|}{ Frequency of citation } \\
\hline & & & & & $\begin{array}{l}\mathrm{Ba} \\
(n=61)\end{array}$ & $\begin{array}{l}\mathrm{Sb} \\
(n=59)\end{array}$ & $\begin{array}{l}\text { Zou } \\
(n=93)\end{array}$ \\
\hline \multicolumn{8}{|c|}{ Aeollanthus pubescens Benth. } \\
\hline \multirow[t]{5}{*}{ Food } & \multirow[t]{4}{*}{ Leaves } & \multirow{4}{*}{$\begin{array}{l}\text { Crush fresh leaves and mix } \\
\text { with seasoning and sesame }\end{array}$} & \multirow[t]{4}{*}{ Eat as sauce } & Human nutrition & - & 17 & - \\
\hline & & & & $\begin{array}{l}\text { Milk production } \\
\text { stimulation for } \\
\text { nursing women }\end{array}$ & - & 1 & - \\
\hline & & & & Diarrhea & - & 2 & - \\
\hline & & & & Intestinal worms & - & 1 & - \\
\hline & Above ground & $\begin{array}{l}\text { Crush and mix with seasoning } \\
\text { and sesame }\end{array}$ & Eat as sauce & $\begin{array}{l}\text { Stop hemorrhage } \\
\text { for nursing women }\end{array}$ & - & 2 & - \\
\hline Medicine & Leaves & Boil in water as decoction & $\begin{array}{l}\text { Drink the liquid } \\
3 \text { times/day }\end{array}$ & Fever & - & 2 & - \\
\hline Other & & $\begin{array}{l}\text { Pound the fresh leaves and } \\
\text { mix with traditional soap koto }\end{array}$ & Take a shower with & $\begin{array}{l}\text { Deodorant for } \\
\text { nursing women }\end{array}$ & - & 1 & - \\
\hline \multicolumn{8}{|c|}{ Aframomum alboviolaceum (Ridley) K.Schum. } \\
\hline \multirow[t]{6}{*}{ Food } & Leaves & $\begin{array}{l}\text { Boil young leaves and mix } \\
\text { with seasoning }\end{array}$ & Eat as vegetable & Human nutrition & & & 1 \\
\hline & \multirow[t]{4}{*}{ Fruits } & \multirow[t]{3}{*}{ Remove the cockleshell } & \multirow[t]{3}{*}{ Eat the pulp } & Human nutrition & 57 & 53 & 86 \\
\hline & & & & Malaria & 1 & 5 & 1 \\
\hline & & & & Cough & - & 1 & - \\
\hline & & $\begin{array}{l}\text { Crushed dried cockleshells as } \\
\text { condiment in sauce }\end{array}$ & Eat & Human nutrition & 2 & - & - \\
\hline & Root & $\begin{array}{l}\text { Crushed roots as aromatic } \\
\text { spice in sauce }\end{array}$ & $\begin{array}{l}\text { Eat as sauce, contra-indicated } \\
\text { with pregnant women }\end{array}$ & $\begin{array}{l}\text { Milk production } \\
\text { stimulation for } \\
\text { nursing women }\end{array}$ & 3 & - & - \\
\hline \multirow[t]{11}{*}{ Medicine } & \multirow[t]{11}{*}{ Leaves } & \multirow[t]{3}{*}{$\begin{array}{l}\text { Boil leaves with stem and } \\
\text { roots in water as decoction }\end{array}$} & $\begin{array}{l}\text { Drink the liquid and take a } \\
\text { shower } 3 \text { times/day }\end{array}$ & Fever and malaria & 5 & 3 & 6 \\
\hline & & & \multirow[t]{2}{*}{ Drink the liquid 2 times/day } & Stomach-ache & - & 1 & - \\
\hline & & & & $\begin{array}{l}\text { Milk production } \\
\text { stimulation for } \\
\text { nursing women }\end{array}$ & 1 & - & - \\
\hline & & $\begin{array}{l}\text { Soak dried leaves in water for } \\
2-3 \text { days }\end{array}$ & $\begin{array}{l}\text { Drink the liquid and take a } \\
\text { shower } 3 \text { times/day }\end{array}$ & Fever and malaria & 1 & - & - \\
\hline & & \multirow{2}{*}{$\begin{array}{l}\text { Boil leaves in water as } \\
\text { decoction }\end{array}$} & Take a shower & Fortify infants & 2 & - & - \\
\hline & & & $\begin{array}{l}\text { Drink the liquid, a glass for } \\
\text { adult, half for children }\end{array}$ & Dermatosis & 1 & - & 1 \\
\hline & & $\begin{array}{l}\text { Boil in water with Caesalpinia } \\
\text { pulcherrima leaves, then add a } \\
\text { piece of sugar }\end{array}$ & Drink a small glass 2 times/day & $\begin{array}{l}\text { Icterus and } \\
\text { yellow-fever }\end{array}$ & 2 & - & - \\
\hline & & Triturate the leaves & Drink the juice 2 times/day & Hemorrhoid & - & - & 1 \\
\hline & & $\begin{array}{l}\text { Boil dried leaves in water as } \\
\text { decoction. Add 2-3 pieces of } \\
\text { sugar }\end{array}$ & Drink the liquid 4-5 times/day & Anemia for children & 1 & - & - \\
\hline & & $\begin{array}{l}\text { Boil in fermented corn water } \\
\text { the yellowed leaves with } A \text {. } \\
\text { angustifolium fruits plus tough } \\
\text { potash }\end{array}$ & Drink a glass/day & Sexual weakness & 1 & - & - \\
\hline & & $\begin{array}{l}\text { Boil in the fermented corn } \\
\text { water yellowed leaves with } \\
\text { cockleshells of } A \text {. angustifolium } \\
\text { fruits and tough potash }\end{array}$ & Drink the liquid 2 times/day & Painful menstruation & 1 & - & - \\
\hline
\end{tabular}


Table 12 List of wild spices, used part, processing methods, and forms and purpose of use (Continued)

\begin{tabular}{|c|c|c|c|c|c|c|c|}
\hline \multirow[t]{2}{*}{ Use category } & \multirow[t]{2}{*}{ Plant part } & \multirow[t]{2}{*}{ Processing method } & \multirow[t]{2}{*}{ Form of use } & \multirow[t]{2}{*}{ Purpose of use } & \multicolumn{3}{|c|}{ Frequency of citation } \\
\hline & & & & & $\begin{array}{l}\mathrm{Ba} \\
(n=61)\end{array}$ & $\begin{array}{l}\mathrm{Sb} \\
(n=59)\end{array}$ & $\begin{array}{l}\text { Zou } \\
(n=93)\end{array}$ \\
\hline & & Fresh leaves & $\begin{array}{l}\text { Rub the leaves juice against } \\
\text { the body }\end{array}$ & $\begin{array}{l}\text { Stop itching or insect } \\
\text { bite }\end{array}$ & - & 1 & - \\
\hline & \multirow[t]{8}{*}{ Fruits } & \multirow{2}{*}{$\begin{array}{l}\text { Remove the cockleshell and } \\
\text { Soak the pulp including the } \\
\text { seeds in water for } 2-3 \mathrm{~h}\end{array}$} & \multirow[t]{2}{*}{ Drink the liquid } & Malaria & 2 & 3 & 3 \\
\hline & & & & Hematuria & - & 1 & - \\
\hline & & $\begin{array}{l}\text { Pound dried cockleshells with } \\
\text { dried seeds of } A \text {. melegueta }\end{array}$ & Make 9 scarifications at the hip & Hip-ache & - & - & 1 \\
\hline & & Remove the cockleshells & $\begin{array}{l}\text { Smell the scent or eat the } \\
\text { pulp }\end{array}$ & $\begin{array}{l}\text { Nausea for pregnant } \\
\text { women }\end{array}$ & 2 & - & - \\
\hline & & Boil in water as decoction & Drink the liquid once the day & Fortify infants & - & - & 1 \\
\hline & & $\begin{array}{l}\text { Boil } 4 \text { fruits with other } \\
\text { ingredients as decoction }\end{array}$ & Drink the liquid 3 times/day & Infertility for women & - & - & 1 \\
\hline & & $\begin{array}{l}\text { Pound fresh fruits and make } \\
\text { small bowls }\end{array}$ & $\begin{array}{l}\text { Insert the bowls in the vagina } \\
\text { before sleeping }\end{array}$ & $\begin{array}{l}\text { Absence of } \\
\text { menstruation }\end{array}$ & 1 & - & - \\
\hline & & Soak in water with roots & Drink the liquid 3 times/day & $\begin{array}{l}\text { Strengthening of } \\
\text { bones }\end{array}$ & 2 & - & - \\
\hline & \multirow[t]{16}{*}{ Root } & \multirow[t]{2}{*}{ Wash fresh roots } & \multirow[t]{2}{*}{ Eat raw and swallow the juice } & Snake bite & - & - & 1 \\
\hline & & & & Stomach-ache & - & - & 1 \\
\hline & & $\begin{array}{l}\text { Pounded fresh roots mix with } \\
\text { other ingredients }\end{array}$ & Make a poultice & Snake bite & 1 & - & 3 \\
\hline & & $\begin{array}{l}\text { Soak in Sodabi or in sorghum } \\
\text { fermented beverage for } \\
2-3 \text { days }\end{array}$ & $\begin{array}{l}\text { Drink a small glass } 2 \text { times/day } \\
\text { - contra-indicated with } \\
\text { pregnant women }\end{array}$ & Stomach-ache & 1 & - & - \\
\hline & & $\begin{array}{l}\text { Soak with 7-8 M. myristica } \\
\text { seeds and } 4 \text { Garcinia kola } \\
\text { seeds }\end{array}$ & Drink the liquid 3 times/day & Sexual weakness & - & - & 1 \\
\hline & & $\begin{array}{l}\text { Dried roots and dried fruits } \\
\text { plus tough potash crushed: } \\
\text { mixed the powder palm } \\
\text { almonds oil }\end{array}$ & $\begin{array}{l}\text { Eat the mixture, on the } \\
\text { morning after eating } \\
\text { something sweetened }\end{array}$ & Intestinal worms & - & 1 & - \\
\hline & & $\begin{array}{l}\text { Crush dried roots with tough } \\
\text { potash as powder }\end{array}$ & Lap 3 times/day & Intestinal worms & - & - & 1 \\
\hline & & $\begin{array}{l}\text { Boil in water with roots of } \\
\text { Imperata cylindrica }\end{array}$ & Drink the liquid 3 times/day & Tuberculosis & 1 & - & - \\
\hline & & \multirow[t]{4}{*}{ Boil in water as decoction } & Rinse the mouth & Tooth decay & 1 & - & - \\
\hline & & & Take a shower & Fever & - & 1 & - \\
\hline & & & $\begin{array}{l}\text { Rub the liquid against the } \\
\text { wound }\end{array}$ & Wound healing & 1 & - & - \\
\hline & & & $\begin{array}{l}\text { Drink the liquid } 3 \text { times/day - } \\
\text { contra-indicated with pregnant } \\
\text { women }\end{array}$ & Malaria & 1 & - & - \\
\hline & & $\begin{array}{l}\text { Crushed with M. myristica } \\
\text { seeds, warm }\end{array}$ & $\begin{array}{l}\text { Rub the mixture against the } \\
\text { body }\end{array}$ & Swelling and edema & 1 & - & - \\
\hline & & $\begin{array}{l}\text { roast with Imperata cylindrica } \\
\text { roots, } 10 \text { pods of } M \text {. myristica, } \\
10 \text { Garcinia kola seeds and } \\
\text { tough potash as powder }\end{array}$ & $\begin{array}{l}\text { Mix with porridge, once on } \\
\text { the morning }\end{array}$ & Infertility for women & - & 1 & - \\
\hline & & Soak in water for 4 days & $\begin{array}{l}\text { Drink the liquid and take a } \\
\text { shower } 2 \text { times/day }\end{array}$ & Fortify the body & - & 1 & - \\
\hline & & $\begin{array}{l}\text { Cut and Soak in the water of } \\
\text { beverage }\end{array}$ & Drink & $\begin{array}{l}\text { Poultry disease } \\
\text { healing }\end{array}$ & - & 1 & - \\
\hline
\end{tabular}


Table 12 List of wild spices, used part, processing methods, and forms and purpose of use (Continued)

\begin{tabular}{|c|c|c|c|c|c|c|c|}
\hline \multirow[t]{2}{*}{ Use category } & \multirow[t]{2}{*}{ Plant part } & \multirow[t]{2}{*}{ Processing method } & \multirow[t]{2}{*}{ Form of use } & \multirow[t]{2}{*}{ Purpose of use } & \multicolumn{3}{|c|}{ Frequency of citation } \\
\hline & & & & & $\begin{array}{l}\mathrm{Ba} \\
(n=61)\end{array}$ & $\begin{array}{l}\mathrm{Sb} \\
(n=59)\end{array}$ & $\begin{array}{l}\text { Zou } \\
(n=93)\end{array}$ \\
\hline & \multirow[t]{3}{*}{ Stem } & $\begin{array}{l}\text { Cut the stem and add } 3 \text { seeds } \\
\text { of } A \text {. melegueta }\end{array}$ & Eat and swallow the juice & Stomach-ache & - & - & 1 \\
\hline & & $\begin{array}{l}\text { Boil in water as decoction, add } \\
\text { shea butter }\end{array}$ & Drink the liquid & Cough & - & 1 & - \\
\hline & & Boil in water as decoction & Drink the liquid 3 times/day & Miscarriage & 1 & - & - \\
\hline & \multirow[t]{3}{*}{ Seeds } & $\begin{array}{l}\text { Macerate in the traditional } \\
\text { palm alcohol (sodabi) dried } \\
\text { seeds with papaya's dried } \\
\text { seeds }\end{array}$ & Drink a small glass 3 times/day & Stomach-ache & 1 & - & - \\
\hline & & $\begin{array}{l}\text { Take some seeds and add with } \\
\text { a Garcinia kola seed }\end{array}$ & Eat & Cough & 1 & - & - \\
\hline & & $\begin{array}{l}\text { roast dried seeds as powder } \\
\text { and mix with porridge }\end{array}$ & Drink the porridge & Vertigo & - & - & - \\
\hline \multirow[t]{4}{*}{ Other } & \multirow[t]{2}{*}{ Leaves } & Triturate the leaves in water & Take a shower & Bad body smells & - & 1 & - \\
\hline & & Fresh leaves & $\begin{array}{l}\text { Wrap up maize based paste } \\
\text { (akassa) }\end{array}$ & Trade & - & - & 5 \\
\hline & \multirow[t]{2}{*}{ Stem } & \multirow[t]{2}{*}{ Fresh stems } & $\begin{array}{l}\text { As string to attach luggage on } \\
\text { the field }\end{array}$ & Home use & - & 6 & - \\
\hline & & & As wipe to punish children & Home use & - & 5 & - \\
\hline Ceremony & Seeds & Dried seeds & $\begin{array}{l}\text { Eaten by fetishist to activate } \\
\text { incantations }\end{array}$ & Magico-religious & - & 2 & - \\
\hline \multicolumn{8}{|c|}{ Aframomum angustifolium (Sonn.) K.Schum. } \\
\hline \multirow[t]{7}{*}{ Food } & \multirow[t]{2}{*}{ Leaves } & \multirow{2}{*}{$\begin{array}{l}\text { Crushed leaves as aromatic } \\
\text { spice in sesame sauce }\end{array}$} & \multirow[t]{2}{*}{ Eat the sauce } & Human nutrition & 2 & - & - \\
\hline & & & & $\begin{array}{l}\text { Stop hemorrhage } \\
\text { for nursing women }\end{array}$ & - & 1 & - \\
\hline & Fruits & Remove the cockleshell & Eat the pulp & Human nutrition & 5 & - & - \\
\hline & \multirow[t]{4}{*}{ Root } & \multirow{4}{*}{$\begin{array}{l}\text { Crushed roots as aromatic } \\
\text { spice in sauce }\end{array}$} & \multirow[t]{4}{*}{ Eat as sauce } & Human nutrition & 1 & - & - \\
\hline & & & & $\begin{array}{l}\text { Fortify nursing } \\
\text { women }\end{array}$ & 1 & - & - \\
\hline & & & & Icterus & 1 & - & - \\
\hline & & & & Headache & 1 & - & - \\
\hline \multirow[t]{10}{*}{ Medicine } & \multirow[t]{4}{*}{ Leaves } & $\begin{array}{l}\text { Crushed leaves mixed with salt } \\
\text { or in sauce }\end{array}$ & $\begin{array}{l}\text { Drink the mixture or eat the } \\
\text { sauce }\end{array}$ & Stomach-ache & 1 & - & - \\
\hline & & Soak fresh leaves in water & Rinse the face 3 times/day & Swelling of the face & - & 1 & - \\
\hline & & Fresh leaves & $\begin{array}{l}\text { Rub the leaves juice against } \\
\text { the face } 3 \text { times/day }\end{array}$ & Swelling of the face & - & 1 & - \\
\hline & & $\begin{array}{l}\text { Leaves, roots and fruits as key } \\
\text { ingredients for the recipe }\end{array}$ & Drink & $\begin{array}{l}\text { Discard snakes and } \\
\text { snake bite healing }\end{array}$ & 1 & - & - \\
\hline & \multirow[t]{4}{*}{ Fruits } & \multirow{2}{*}{$\begin{array}{l}\text { Remove the cockleshell and } \\
\text { Soak the pulp including the } \\
\text { seeds in water }\end{array}$} & \multirow[t]{2}{*}{ Drink the liquid } & Malaria & 1 & - & - \\
\hline & & & & Hematuria & - & 1 & - \\
\hline & & $\begin{array}{l}\text { Crush or pound and mix with } \\
\text { shea butter }\end{array}$ & $\begin{array}{l}\text { Rub the mixture against the } \\
\text { body }\end{array}$ & Ache & 1 & - & - \\
\hline & & Soak in water with roots & Drink the liquid 3 times/day & $\begin{array}{l}\text { Strengthening of } \\
\text { bones }\end{array}$ & 1 & - & - \\
\hline & \multirow[t]{2}{*}{ Root } & $\begin{array}{l}\text { Boil in water as decoction with } \\
\text { potash }\end{array}$ & Drink the liquid & Anemia & - & 1 & - \\
\hline & & Crush or pound fresh roots & $\begin{array}{l}\text { Rub the mixture against the } \\
\text { body }\end{array}$ & Swelling and edema & 1 & 2 & - \\
\hline
\end{tabular}


Table 12 List of wild spices, used part, processing methods, and forms and purpose of use (Continued)

\begin{tabular}{|c|c|c|c|c|c|c|c|}
\hline \multirow[t]{2}{*}{ Use category } & \multirow[t]{2}{*}{ Plant part } & \multirow[t]{2}{*}{ Processing method } & \multirow[t]{2}{*}{ Form of use } & \multirow[t]{2}{*}{ Purpose of use } & \multicolumn{3}{|c|}{ Frequency of citation } \\
\hline & & & & & $\begin{array}{l}\mathrm{Ba} \\
(n=61)\end{array}$ & $\begin{array}{l}\mathrm{Sb} \\
(n=59)\end{array}$ & $\begin{array}{l}\text { Zou } \\
(n=93)\end{array}$ \\
\hline & & Crush or pound fresh roots & $\begin{array}{l}\text { Rub the mixture against the } \\
\text { head }\end{array}$ & Headache & 7 & - & - \\
\hline & & \multirow[t]{2}{*}{ Boil in water as decoction } & \multirow[t]{2}{*}{ Take a shower } & Ache & - & 1 & - \\
\hline & & & & Fever & - & 1 & - \\
\hline & & Crush or pound fresh roots & Put a little in the nostrils & Cold & 1 & - & - \\
\hline & & Crush fresh roots & $\begin{array}{l}\text { Put the paste obtained on the } \\
\text { decayed tooth }\end{array}$ & Tooth decay & - & 1 & - \\
\hline & & $\begin{array}{l}\text { Soak in water for } 5 \text { min the } \\
\text { crushed fresh roots }\end{array}$ & $\begin{array}{l}\text { Rub against the head and } \\
\text { rinse the face }\end{array}$ & Vertigo & - & 1 & - \\
\hline & & $\begin{array}{l}\text { Soak in water with fruits } \\
\text { peduncle and leave under the } \\
\text { sun }\end{array}$ & Take a shower & Measles & 1 & - & - \\
\hline & \multirow[t]{2}{*}{ Stem } & $\begin{array}{l}\text { Soak in germinated corn } \\
\text { beverage }\end{array}$ & Rinse the face & Swelling of the face & - & 1 & - \\
\hline & & Cut the fresh stems & Eat and swallow the sap & Cough & 1 & - & - \\
\hline \multirow[t]{2}{*}{ Other } & \multirow[t]{2}{*}{ Stem } & \multirow[t]{2}{*}{ Fresh stems } & $\begin{array}{l}\text { As string to attach luggage on } \\
\text { the field }\end{array}$ & Home use & - & 2 & - \\
\hline & & & As wipe to punish children & Home use & - & 1 & - \\
\hline Ceremony & Seeds & Dried seeds & $\begin{array}{l}\text { Eaten by fetishist to activate } \\
\text { incantations }\end{array}$ & Magico-religious & 1 & 1 & - \\
\hline \multicolumn{8}{|c|}{ Aframomum melegueta (Roscoe) } \\
\hline \multirow[t]{11}{*}{ Medicine } & \multirow[t]{4}{*}{ Fruits } & \multirow{2}{*}{$\begin{array}{l}\text { Remove the cockleshell and } \\
\text { Soak the pulp including the } \\
\text { seeds in water }\end{array}$} & \multirow[t]{2}{*}{ Drink the liquid } & Malaria & 1 & - & - \\
\hline & & & & Hematuria & - & 1 & - \\
\hline & & $\begin{array}{l}\text { Crush or pound and mix with } \\
\text { shea butter }\end{array}$ & $\begin{array}{l}\text { Rub the mixture against the } \\
\text { body }\end{array}$ & Ache & 1 & - & - \\
\hline & & Soak in water with roots & Drink the liquid 3 times/day & $\begin{array}{l}\text { Strengthening of } \\
\text { bones }\end{array}$ & 1 & - & - \\
\hline & Root & Sock in palm wine & $\begin{array}{l}\text { Drink the liquid for } 9 \text { days } \\
\text { (men) or } 7 \text { day (women) }\end{array}$ & Asthenia & - & - & 1 \\
\hline & \multirow[t]{6}{*}{ Seeds } & \multirow[t]{2}{*}{$\begin{array}{l}\text { Crush dried seeds and mix } \\
\text { with water }\end{array}$} & $\begin{array}{l}\text { Drink the liquid and drip on } \\
\text { the eyes, contra-indicated with } \\
\text { pregnant women }\end{array}$ & Anemia & - & - & 1 \\
\hline & & & $\begin{array}{l}\text { Drink the liquid } 2-3 \text { times/day, } \\
\text { contra-indicated with pregnant } \\
\text { women }\end{array}$ & Diarrhea & - & - & 1 \\
\hline & & $\begin{array}{l}\text { Crush dried seeds and mix } \\
\text { with palm alcohol }\end{array}$ & $\begin{array}{l}\text { Drink the liquid } 2 \text { times/day, } \\
\text { contra-indicated with pregnant } \\
\text { women }\end{array}$ & Stomach-ache & - & - & 1 \\
\hline & & Soak with X. aethiopica fruits & $\begin{array}{l}\text { Drink a small glass } 2 \text { times/ } \\
\text { day, contra-indicated with } \\
\text { pregnant women }\end{array}$ & Stomach-ache & - & - & 1 \\
\hline & & Crush dried seeds as powder & $\begin{array}{l}\text { Make scarifications for } 9 \text { days } \\
\text { (men) or } 7 \text { days (women) }\end{array}$ & Paralysis & - & - & 1 \\
\hline & & $\begin{array}{l}\text { Soak in palm alcohol with } P \text {. } \\
\text { guineense and } X \text {. aethiopica } \\
\text { fruits, ginger and lemon }\end{array}$ & $\begin{array}{l}\text { Drink the liquid } 3 \text { times/day, } \\
\text { contra-indicated with pregnant } \\
\text { women }\end{array}$ & Ulcer & - & - & 1 \\
\hline Ceremony & Seeds & Dried seeds & $\begin{array}{l}\text { Eaten by fetishist to activate } \\
\text { incantations }\end{array}$ & Magico-religious & - & - & 10 \\
\hline \multicolumn{8}{|c|}{ Clausena anisata (Willd.) Hook.f. ex Benth. } \\
\hline Medicine & Leaves & Boil in water as decoction & Take a shower & Dermatosis & - & - & 1 \\
\hline
\end{tabular}


Table 12 List of wild spices, used part, processing methods, and forms and purpose of use (Continued)

\begin{tabular}{|c|c|c|c|c|c|c|c|}
\hline \multirow[t]{2}{*}{ Use category } & \multirow[t]{2}{*}{ Plant part } & \multirow[t]{2}{*}{ Processing method } & \multirow[t]{2}{*}{ Form of use } & \multirow[t]{2}{*}{ Purpose of use } & \multicolumn{3}{|c|}{ Frequency of citation } \\
\hline & & & & & $\begin{array}{l}\mathrm{Ba} \\
(n=61)\end{array}$ & $\begin{array}{l}\mathrm{Sb} \\
(n=59)\end{array}$ & $\begin{array}{l}\text { Zou } \\
(n=93)\end{array}$ \\
\hline & Root & Boil in water as decoction & Drink the liquid 2 times/day & Hemorrhoid & - & - & 1 \\
\hline Ceremony & Leaves & Fresh leaves & $\begin{array}{l}\text { Make magic to counter } \\
\text { tchakatou dark magic }\end{array}$ & Magico-religious & - & - & 1 \\
\hline \multicolumn{8}{|c|}{ Cymbopogon giganteus (Hochst.) Chiov. } \\
\hline Food & Leaves & $\begin{array}{l}\text { Attach the leaves and use as } \\
\text { aromatic in Cleome gynandra } \\
\text { leaves sauce }\end{array}$ & Eat the sauce & Human nutrition & - & - & 2 \\
\hline \multicolumn{8}{|c|}{ Lippia multiflora Moldenke } \\
\hline \multirow[t]{12}{*}{ Food } & \multirow[t]{6}{*}{ Leaves } & $\begin{array}{l}\text { Crush the young shoots and } \\
\text { mix with seasoning and } \\
\text { crushed sesame or peanut as } \\
\text { aromatic spices }\end{array}$ & \multirow[t]{2}{*}{ Eat the sauce } & \multirow[t]{2}{*}{ Human nutrition } & 49 & 54 & 29 \\
\hline & & $\begin{array}{l}\text { Boil in water and mix with } \\
\text { seasoning as vegetable sauce }\end{array}$ & & & 1 & - & 2 \\
\hline & & Dry and reduce in powder & Sprinkle the sauce & Human nutrition & 43 & 35 & 17 \\
\hline & & $\begin{array}{l}\text { Boil fresh leaves in water with } \\
\text { corn }\end{array}$ & Eat & Human nutrition & - & 2 & 2 \\
\hline & & $\begin{array}{l}\text { Soak in water with corn and } \\
\text { grind }\end{array}$ & Eat as akassa & Human nutrition & - & - & 1 \\
\hline & & $\begin{array}{l}\text { Infuse dried leaves in warm } \\
\text { water as aromatic tea }\end{array}$ & Drink the tea & Human nutrition & 1 & 1 & - \\
\hline & \multirow[t]{6}{*}{ Flower } & \multirow{5}{*}{$\begin{array}{l}\text { Dried flowers in whole or } \\
\text { crushed }\end{array}$} & \multirow[t]{5}{*}{ Sprinkle the sauce } & Human nutrition & 44 & 35 & 17 \\
\hline & & & & $\begin{array}{l}\text { Milk production } \\
\text { stimulation for } \\
\text { nursing women }\end{array}$ & 2 & 1 & - \\
\hline & & & & $\begin{array}{l}\text { Healing uterine } \\
\text { wounds for nursing } \\
\text { women }\end{array}$ & 3 & 1 & - \\
\hline & & & & $\begin{array}{l}\text { Indigestion, } \\
\text { constipation and } \\
\text { stomach-ache }\end{array}$ & 8 & 5 & - \\
\hline & & & & $\begin{array}{l}\text { Dysentery and } \\
\text { Hemorrhoid }\end{array}$ & 2 & 1 & - \\
\hline & & $\begin{array}{l}\text { Boil flower or leaves in water } \\
\text { with seasoning as spice for } \\
\text { spicy meat }\end{array}$ & Eat & Human nutrition & - & 1 & 5 \\
\hline \multirow[t]{10}{*}{ Medicine } & \multirow[t]{10}{*}{ Leaves } & \multirow[t]{7}{*}{ Boil in water as decoction } & \multirow{5}{*}{$\begin{array}{l}\text { Drink the liquid and take a } \\
\text { shower } 3 \text { times/day }\end{array}$} & Fever and malaria & 6 & 9 & 25 \\
\hline & & & & Fortify infants & 2 & 5 & 6 \\
\hline & & & & $\begin{array}{l}\text { constipation and } \\
\text { Stomach-ache }\end{array}$ & 1 & 1 & 7 \\
\hline & & & & Diarrhea & - & 3 & - \\
\hline & & & & Measles & 1 & 1 & - \\
\hline & & & $\begin{array}{l}\text { Cover the head and take a } \\
\text { steam bath }\end{array}$ & Headache & 2 & - & - \\
\hline & & & Rinse the eyes & Sore eyes & - & - & 1 \\
\hline & & $\begin{array}{l}\text { Boil in water as decoction or } \\
\text { Soak in alcohol }\end{array}$ & Drink the liquid & Blood-pressure & 3 & - & - \\
\hline & & \multirow{2}{*}{$\begin{array}{l}\text { Boil in water with stem and } \\
\text { roots as decoction }\end{array}$} & & Cold and cough & 2 & - & 2 \\
\hline & & & & $\begin{array}{l}\text { Dysentery and } \\
\text { Hemorrhoid }\end{array}$ & - & 1 & 2 \\
\hline
\end{tabular}


Table 12 List of wild spices, used part, processing methods, and forms and purpose of use (Continued)

\begin{tabular}{|c|c|c|c|c|c|c|c|}
\hline \multirow[t]{2}{*}{ Use category } & \multirow[t]{2}{*}{ Plant part } & \multirow[t]{2}{*}{ Processing method } & \multirow[t]{2}{*}{ Form of use } & \multirow[t]{2}{*}{ Purpose of use } & \multicolumn{3}{|c|}{ Frequency of citation } \\
\hline & & & & & $\begin{array}{l}\mathrm{Ba} \\
(n=61)\end{array}$ & $\begin{array}{l}\mathrm{Sb} \\
(n=59)\end{array}$ & $\begin{array}{l}\text { Zou } \\
(n=93)\end{array}$ \\
\hline & & & $\begin{array}{l}\text { Drink the liquid and rinse the } \\
\text { body or take a shower } 2 \\
\text { times/day }\end{array}$ & $\begin{array}{l}\text { Dermatosis and } \\
\text { wound healing }\end{array}$ & - & 2 & 5 \\
\hline & & Boil in water leaves and roots & Drink the liquid & $\begin{array}{l}\text { Healing uterine } \\
\text { wounds for nursing } \\
\text { women }\end{array}$ & 4 & - & - \\
\hline & & & & Nausea and vomiting & 3 & 1 & - \\
\hline & & Triturate the leaves & $\begin{array}{l}\text { Inhale the gas and drip on the } \\
\text { eyes }\end{array}$ & Headache & - & - & 1 \\
\hline & & & Put the juice into the nostrils & Cold & - & - & 1 \\
\hline & & & $\begin{array}{l}\text { Drink the juice before going to } \\
\text { hospital }\end{array}$ & Snake bite & 1 & - & - \\
\hline & & Fresh leaves & Eat and swallow the juice & Cough & - & - & - \\
\hline & Root & Boil in water as decoction & Drink the liquid 2-3 times/day & Anemia for children & 1 & - & 1 \\
\hline & & & & Nausea and vomiting & 10 & - & - \\
\hline & & & & $\begin{array}{l}\text { Indigestion and } \\
\text { Stomach-ache }\end{array}$ & 2 & 9 & - \\
\hline & & & & Diarrhea & - & 1 & - \\
\hline & & & & Ulcer & - & 2 & - \\
\hline & & & & Intestinal worms & 2 & - & - \\
\hline & & & Drink the liquid and take a & Fever and malaria & - & 12 & 2 \\
\hline & & & shower & Fortify infants & - & 3 & - \\
\hline & & $\begin{array}{l}\text { Boil in water as decoction with } \\
\text { small red onions, } X \text {. aethiopica } \\
\text { fruits and } M \text {. myristica seeds }\end{array}$ & $\begin{array}{l}\text { Drink the liquid and take a } \\
\text { shower }\end{array}$ & $\begin{array}{l}\text { Dermatosis and } \\
\text { wound healing }\end{array}$ & - & 7 & 1 \\
\hline & & Crush or pound fresh roots & $\begin{array}{l}\text { Rub the mixture against the } \\
\text { body }\end{array}$ & Swelling and edema & 1 & - & 1 \\
\hline & & Soak in water for $2 \mathrm{~h}$ & Drink the liquid 3 times/day & Painful menstruation & 1 & - & - \\
\hline & & $\begin{array}{l}\text { Soak in water for } 3 \text { days with } \\
X \text {. aethiopica fruits }\end{array}$ & Rinse the eyes & Sore eyes & - & 1 & - \\
\hline & & $\begin{array}{l}\text { Crush dried roots with } 9 \text { A. } \\
\text { melegueta seeds and } X \text {. } \\
\text { aethiopica fruit as powder }\end{array}$ & Inhale the powder & Headache & 1 & - & - \\
\hline & Stem & Boil in water as decoction & Drink the liquid 3 times/day & Asthma & - & 1 & - \\
\hline Cultural & Flower & Dried flowers & Use to spicy sauce & Food & - & 21 & - \\
\hline \multicolumn{8}{|c|}{ Monodora tenuifolia Benth. } \\
\hline \multirow[t]{2}{*}{ Food } & Seeds & $\begin{array}{l}\text { Roast the seed to remove the } \\
\text { cockleshells and crush the } \\
\text { almond, use as aromatic spice } \\
\text { in sauce }\end{array}$ & Eat the sauce & Human nutrition & - & - & 1 \\
\hline & & $\begin{array}{l}\text { Crush almonds with } X \text {. } \\
\text { aethiopica fruits and mix with } \\
\text { pepper, chili, other spices and } \\
\text { seasoning }\end{array}$ & Eat as sauce & Stomach-ache & - & - & 1 \\
\hline \multirow[t]{3}{*}{ Medicine } & \multirow[t]{3}{*}{ Seeds } & \multirow{2}{*}{$\begin{array}{l}\text { Boil in water with } X \text {. aethiopica } \\
\text { fruits, U. chamae roots and } \\
\text { small red onions }\end{array}$} & \multirow[t]{2}{*}{ Drink the liquid 3 times/day } & Stomach-ache & - & - & 1 \\
\hline & & & & $\begin{array}{l}\text { Black menstruations } \\
\text { and absence of } \\
\text { menstruations }\end{array}$ & - & - & 1 \\
\hline & & $\begin{array}{l}\text { Crush the almond and mix } \\
\text { with palm almond oil }\end{array}$ & $\begin{array}{l}\text { Rub the mixture against the } \\
\text { body }\end{array}$ & Fever & - & - & 1 \\
\hline
\end{tabular}


Table 12 List of wild spices, used part, processing methods, and forms and purpose of use (Continued)

\begin{tabular}{|c|c|c|c|c|c|c|c|}
\hline \multirow[t]{2}{*}{ Use category } & \multirow[t]{2}{*}{ Plant part } & \multirow[t]{2}{*}{ Processing method } & \multirow[t]{2}{*}{ Form of use } & \multirow[t]{2}{*}{ Purpose of use } & \multicolumn{3}{|c|}{ Frequency of citation } \\
\hline & & & & & $\begin{array}{l}\mathrm{Ba} \\
(n=61)\end{array}$ & $\begin{array}{l}\mathrm{Sb} \\
(n=59)\end{array}$ & $\begin{array}{l}\text { Zou } \\
(n=93)\end{array}$ \\
\hline & & Boil in water as decoction & Take a shower & Fever & - & - & 1 \\
\hline & Flower & $\begin{array}{l}\text { Char flowers with } U \text {. chamae } \\
\text { roots as powder and an } A \text {. } \\
\text { melegueta fruit pod }\end{array}$ & Sprinkle wounds & $\begin{array}{l}\text { Incurable wounds } \\
\text { healing }\end{array}$ & - & - & 1 \\
\hline & Bark & $\begin{array}{l}\text { Crush dried bark and } 7 \mathrm{~A} \text {. } \\
\text { melegueta seeds as powder } \\
\text { and mix with palm almond oil }\end{array}$ & Put the mixture in the wounds & Wound healing & - & - & 1 \\
\hline & & Soak fresh barks in the water & Rinse a wound & Wound healing & - & - & 1 \\
\hline & Root & $\begin{array}{l}\text { Pound dried roots and mix } \\
\text { with sugar and sulfur as } \\
\text { powder }\end{array}$ & $\begin{array}{l}\text { Mix the powder with the } \\
\text { porridge }\end{array}$ & $\begin{array}{l}\text { Dysentery and } \\
\text { Hemorrhoid }\end{array}$ & - & - & 1 \\
\hline Ceremony & Seeds & Dried seeds & $\begin{array}{l}\text { Used by fetishist for various } \\
\text { ceremonies }\end{array}$ & Magico-religious & - & - & 4 \\
\hline \multicolumn{8}{|c|}{ Piper guineense Schumach. \& Thonn. } \\
\hline \multirow[t]{4}{*}{ Food } & Leaves & $\begin{array}{l}\text { Fresh leaves crushed or in } \\
\text { whole as aromatic spice in } \\
\text { sauce }\end{array}$ & Eat & Human nutrition & - & - & 13 \\
\hline & Fruits & $\begin{array}{l}\text { Crush dried fruits and mix with } \\
\text { seasoning }\end{array}$ & & & - & - & 11 \\
\hline & Stem & $\begin{array}{l}\text { Cut fresh stems and put in the } \\
\text { sauce }\end{array}$ & & & - & - & 2 \\
\hline & Root & Put fresh roots in the sauce & & & - & - & 1 \\
\hline \multirow[t]{6}{*}{ Medicine } & Leaves & Boil in water as decoction & Drink the liquid & Dermatosis & - & - & 1 \\
\hline & Fruits & $\begin{array}{l}\text { Sock in water dried fruits with } \\
\text { ginger and fruit of } X \text {. } \\
\text { aethiopica }\end{array}$ & $\begin{array}{l}\text { Drink the liquid, contra- } \\
\text { indicated with pregnant } \\
\text { women }\end{array}$ & Dermatosis & - & - & 1 \\
\hline & & \multirow{2}{*}{$\begin{array}{l}\text { Soak in alcohol dried fruits } \\
\text { with } A \text {. melegueta and } X \text {. } \\
\text { aethiopica fruits }\end{array}$} & & Ulcer & - & - & 1 \\
\hline & & & & Hematuria & - & - & 1 \\
\hline & & Soak dried fruits in alcohol & Drink the liquid 2 times/day & Blood-pressure & - & - & 1 \\
\hline & & $\begin{array}{l}\text { Crush dried fruits and mix with } \\
\text { salt }\end{array}$ & Drink the mixture & & - & - & - \\
\hline Ceremony & Fruits & Dried fruits & $\begin{array}{l}\text { Used by fetishist for } \\
\text { ceremonies of fâ }\end{array}$ & Magico-religious & - & - & 5 \\
\hline \multicolumn{8}{|c|}{ Securidaca longipedunculata Fresen. } \\
\hline \multirow[t]{4}{*}{ Medicine } & Root & Crush or pound the roots & Make a poultice & Edema and abscess & - & - & 2 \\
\hline & & $\begin{array}{l}\text { Soak in water with } X \text {. } \\
\text { aethiopica fruits and } M \text {. } \\
\text { myristica seeds }\end{array}$ & Drink the liquid & antibiotic & - & - & 1 \\
\hline & & $\begin{array}{l}\text { Boil in water with } U \text {. chamae } \\
\text { and } Z \text {. zanthoxyloides roots, } X \text {. } \\
\text { aethiopica fruits, } M \text {. myristica } \\
\text { seeds and small red onions }\end{array}$ & Drink the liquid once the day & Stomach-ache & - & - & 1 \\
\hline & & $\begin{array}{l}\text { Soak in alcohol with garlic and } \\
\text { A. melegueta seeds }\end{array}$ & Drink the liquid & Fever & - & - & 1 \\
\hline \multicolumn{8}{|c|}{ Thonningia sanguinea Vahl } \\
\hline \multirow[t]{2}{*}{ Medicine } & Root & Rub against a rock & $\begin{array}{l}\text { Rub the root juice against the } \\
\text { body }\end{array}$ & $\begin{array}{l}\text { Edema, abscess, } \\
\text { swelling, wound and } \\
\text { mumps }\end{array}$ & 10 & - & 1 \\
\hline & & $\begin{array}{l}\text { Dry and reduce in powder the } \\
\text { roots with papaya roots and } \\
\text { fruits of } A \text {. melegueta }\end{array}$ & & Hemorrhoid & 1 & - & - \\
\hline
\end{tabular}


Table 12 List of wild spices, used part, processing methods, and forms and purpose of use (Continued)

\begin{tabular}{|c|c|c|c|c|c|c|c|}
\hline \multirow[t]{2}{*}{ Use category } & \multirow[t]{2}{*}{ Plant part } & \multirow[t]{2}{*}{ Processing method } & \multirow[t]{2}{*}{ Form of use } & \multirow[t]{2}{*}{ Purpose of use } & \multicolumn{3}{|c|}{ Frequency of citation } \\
\hline & & & & & $\begin{array}{l}\mathrm{Ba} \\
(n=61)\end{array}$ & $\begin{array}{l}\mathrm{Sb} \\
(n=59)\end{array}$ & $\begin{array}{l}\text { Zou } \\
(n=93)\end{array}$ \\
\hline & & Crush the roots & Rub the past against the body & Guinea-worm disease & - & - & 1 \\
\hline \multicolumn{8}{|c|}{ Uvaria chamae P.Beauv. } \\
\hline \multirow[t]{2}{*}{ Food } & Fruits & Ripe fruit & Eat & Human nutrition & - & - & 1 \\
\hline & Root & $\begin{array}{l}\text { Crush and mix with seasoning } \\
\text { as aromatic spice }\end{array}$ & Eat & Human nutrition & - & - & 1 \\
\hline \multirow[t]{3}{*}{ Medicine } & Leaves & Boil in water as decoction & Take a shower & Fever & - & - & 1 \\
\hline & Root & $\begin{array}{l}\text { Soak in alcohol with } X \text {. } \\
\text { aethiopica fruits, M. myristica } \\
\text { and } A \text {. melegueta seeds }\end{array}$ & Drink the liquid 2 times/day & Stomach-ache & - & - & 2 \\
\hline & & $\begin{array}{l}\text { Boil in water with ripe palm } \\
\text { fruits }\end{array}$ & Drink the liquid & Anemia & - & - & 1 \\
\hline \multicolumn{8}{|c|}{ Xylopia aethiopica (Dunal) A.Rich. } \\
\hline \multirow[t]{6}{*}{ Medicine } & \multirow[t]{6}{*}{ Fruits } & $\begin{array}{l}\text { Boil or soak in water with } A \text {. } \\
\text { melegueta seeds }\end{array}$ & Drink the liquid 3 times/day & Stomach-ache & - & - & 3 \\
\hline & & Dried fruits & $\begin{array}{l}\text { Eat the fruit and swallow the } \\
\text { juice }\end{array}$ & Nausea and vomiting & - & - & 1 \\
\hline & & $\begin{array}{l}\text { Boil in water with other } \\
\text { ingredients as decoction }\end{array}$ & Drink the liquid & Infertility for women & - & - & 2 \\
\hline & & Boil in water as decoction & Drink the liquid & Fortify infants & - & - & 1 \\
\hline & & $\begin{array}{l}\text { Crush dried fruits and mix with } \\
\text { alcohol }\end{array}$ & $\begin{array}{l}\text { Rub the mixture against the } \\
\text { body }\end{array}$ & $\begin{array}{l}\text { Edema, swelling and } \\
\text { dermatosis }\end{array}$ & - & - & 2 \\
\hline & & $\begin{array}{l}\text { Crush dried fruits as powder } \\
\text { and mix with sugar }\end{array}$ & $\begin{array}{l}\text { Mix the powder with the } \\
\text { beverage and drink }\end{array}$ & Asthenia & - & - & 1 \\
\hline Ceremony & Fruits & Dried fruits & $\begin{array}{l}\text { Used by fetishist for various } \\
\text { ceremonies }\end{array}$ & Magico-religious & - & - & 2 \\
\hline \multicolumn{8}{|c|}{ Zanthoxylum zanthoxyloides (Lam.) Zepernick \& Timler } \\
\hline \multirow[t]{5}{*}{ Food } & \multirow[t]{5}{*}{ Root } & \multirow{5}{*}{$\begin{array}{l}\text { Remove, dry and crush roots' } \\
\text { barks as powder }\end{array}$} & \multirow{5}{*}{$\begin{array}{l}\text { Spicy sauces and eat, contra- } \\
\text { indica with pregnant women }\end{array}$} & Human nutrition & 25 & - & - \\
\hline & & & & $\begin{array}{l}\text { Milk production } \\
\text { stimulation for } \\
\text { nursing women }\end{array}$ & 9 & - & - \\
\hline & & & & $\begin{array}{l}\text { Stomach-ache and } \\
\text { ulcer }\end{array}$ & 4 & - & - \\
\hline & & & & $\begin{array}{l}\text { Dysentery and } \\
\text { diarrhea }\end{array}$ & 2 & - & - \\
\hline & & & & $\begin{array}{l}\text { Healing uterine } \\
\text { wounds for nursing } \\
\text { women }\end{array}$ & 5 & - & - \\
\hline \multirow[t]{7}{*}{ Medicine } & \multirow[t]{7}{*}{ Root } & \multirow{4}{*}{$\begin{array}{l}\text { Soak the roots' barks in } \\
\text { alcohol }\end{array}$} & \multirow{5}{*}{$\begin{array}{l}\text { Drink the liquid } 2-3 \text { times/day, } \\
\text { contra-indicated with pregnant } \\
\text { women }\end{array}$} & Stomach-ache & 14 & - & - \\
\hline & & & & Nausea and vomiting & 1 & - & - \\
\hline & & & & Intestinal worms & 1 & - & - \\
\hline & & & & Sexual weakness & 1 & - & - \\
\hline & & $\begin{array}{l}\text { Soak the roots' barks in } \\
\text { alcohol with } A \text {. melegueta } \\
\text { seeds }\end{array}$ & & Abortion & 2 & - & - \\
\hline & & \multirow{2}{*}{$\begin{array}{l}\text { Soak the roots' barks in } \\
\text { alcohol with garlic, pepper, } \\
\text { chili, } X \text {. aethiopica fruits, } M \text {. } \\
\text { myristica and A. melegueta } \\
\text { seeds }\end{array}$} & \multirow{2}{*}{$\begin{array}{l}\text { Drink the liquid } 2-3 \text { times/day, } \\
\text { contra-indicated with pregnant } \\
\text { women }\end{array}$} & Ulcer & 3 & - & - \\
\hline & & & & Menstruation issue & 1 & - & - \\
\hline
\end{tabular}


Table 12 List of wild spices, used part, processing methods, and forms and purpose of use (Continued)

\begin{tabular}{|c|c|c|c|c|c|c|c|}
\hline \multirow[t]{2}{*}{ Use category } & \multirow[t]{2}{*}{ Plant part } & \multirow[t]{2}{*}{ Processing method } & \multirow[t]{2}{*}{ Form of use } & \multirow[t]{2}{*}{ Purpose of use } & \multicolumn{3}{|c|}{ Frequency of citation } \\
\hline & & & & & $\begin{array}{l}\mathrm{Ba} \\
(n=61)\end{array}$ & $\begin{array}{l}\mathrm{Sb} \\
(n=59)\end{array}$ & $\begin{array}{l}\text { Zou } \\
(n=93)\end{array}$ \\
\hline & & $\begin{array}{l}\text { Boil in water the roots' barks } \\
\text { with garlic, pepper, chili, } X \text {. } \\
\text { aethiopica fruits, } M \text {. myristica } \\
\text { and } A \text {. melegueta seeds }\end{array}$ & $\begin{array}{l}\text { Drink the liquid } 2-3 \text { times/day, } \\
\text { contra-indicated with pregnant } \\
\text { women }\end{array}$ & $\begin{array}{l}\text { Sexually transmissible } \\
\text { infections }\end{array}$ & 1 & - & - \\
\hline & & $\begin{array}{l}\text { Boil in water the roots' barks } \\
\text { with ginger leaves as } \\
\text { decoction }\end{array}$ & Drink the liquid & $\begin{array}{l}\text { Painful and dark } \\
\text { menstruation }\end{array}$ & 2 & - & - \\
\hline
\end{tabular}

$\mathrm{Ba}$ Bassila, Sb South-Borgou

\section{Discussion}

\section{Diversity of the wild spices across phytodistricts}

A total of 14 wild spices was recorded throughout the Sudano-Guinean zone. This species richness seems relatively low when compared to that reported from a similar study conducted in the Niger Delta area in Nigeria (24 species) [52]. This difference could come from the location of part of Benin in the Dahomey-Gap, an approximately 200-km-wide savanna corridor from Ghana to Benin, separating the Upper and the Lower Guinean rain forest blocks [53]. This phenomenon does not allow an impressive biological diversity but rather induced a relatively few number of endemic species to Benin as most species are shared with neighboring countries. This situation added to NTFPs' overexploitation, climate change, and raging demography with its subsequent consequences, increasingly compromises indigenous species persistence, thus, leading to the scarcity or disappearance of critical species $[8,54]$. Further, extensive land use and cover transitions and the intensification of human pressure in the surrounding of protected areas increases the vulnerability of species [55]. Consequently, the wild spices should be conserved through their integration in the traditional agroforestry systems.
Wild species used as spices in the Sudano-Guinean zone belong mainly to the families of Zingiberaceae, Annonaceae, and Rutaceae which are well-known for holding much of aromatic plants and spices [56]. The inventoried wild spices richness was predominated by Afrotropical and Guineo-Congolian species and a low representation of Sudano-Guinean species. This could be explained by human migration associated with seed dispersal and propagation of the species across areas, ruling out isolation by distance, as reported for Caesalpinia bonduc L. [57]. Likewise, the genetic diversity and genetic differentiation might be low for these species, due to parental links between populations. This may reduce their ability to survive and adapt to changing environmental conditions.

\section{Traditional knowledge, informant consensus, cultural} importance and use value of the wild spices

The study showed how Traditional knowledge (TK) of wild spices is structured in the Sudano-Guinean Zone. Our results support the general hypothesis that TK depends on geographical location, sociolinguistic group, and gender [58]. Indeed, people in Bassila phytodistrict held the greatest level of knowledge, and regarding the

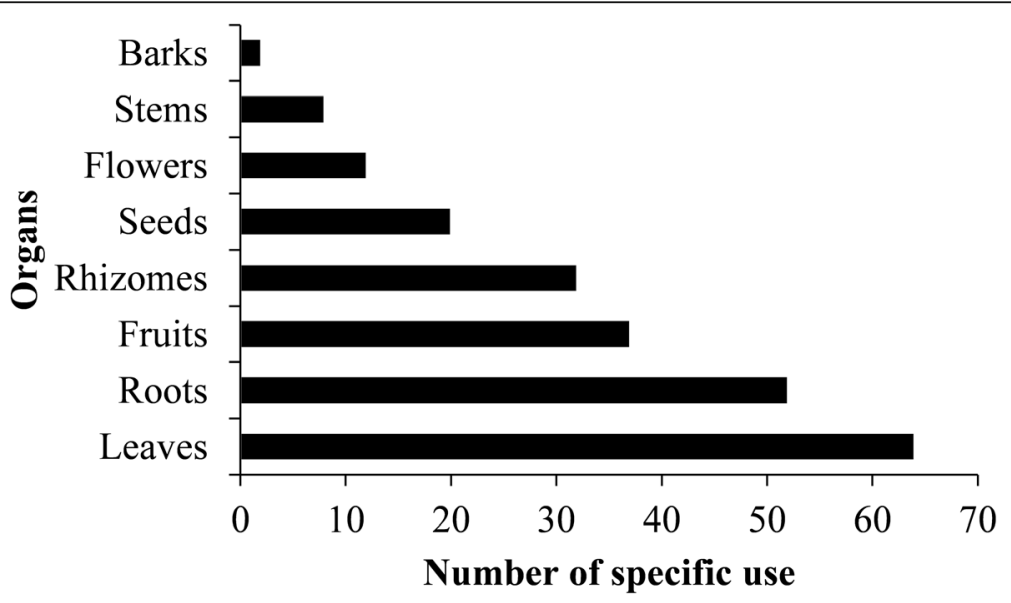

Fig. 10 Number of specific use for each plant part of wild spice in the Sudano-Guinean Zone 


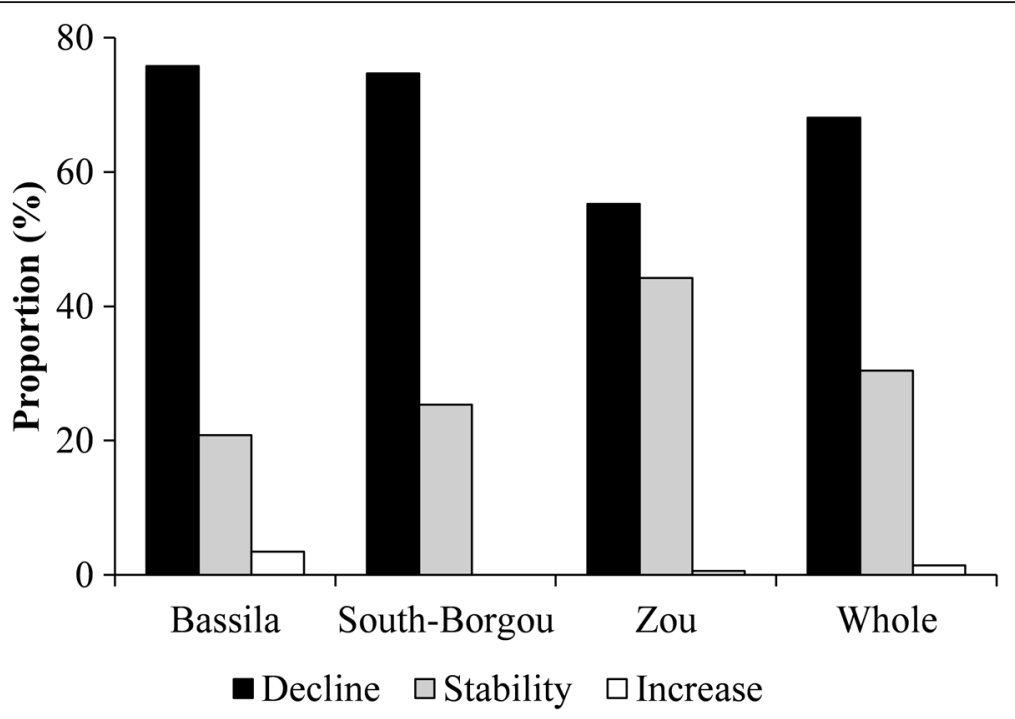

Fig. 11 Local perception of the dynamic of wild spice populations by phytodistrict

sociolinguistic difference in TK, Tchabè informants from Bassila reported more uses than other sociolinguistic groups. This suggests that the wild spices are mostly used in the Bassila phytodistrict and less in the Zou and South-Borgou phytodistricts. Male informants reported more uses than female ones. Although this finding does not confirm the general statement that women are reservoirs of traditional plant knowledge [59], similar findings have been reported in Benin [60,61] and Mexico [62]. As suggested by Voeks [59], this might be due to gender division of the space and labor.
The most culturally important wild spices as revealed from our data were, by order of importance, $L$. multiflora, A. alboviolaceum, and Z. zanthoxyloides. People in Bassila phytodistrict culturally valued more wild spices than those from the other phytodistricts. This is congruent with the TK pattern of wild spices. The two species with the highest cultural importance $(\mathrm{CI})$ value were the most quoted in all three phytodistricts. This similarity may have resulted from a common cultural background. Irrespective of gender and age category, studied sociolinguistic groups valued different wild

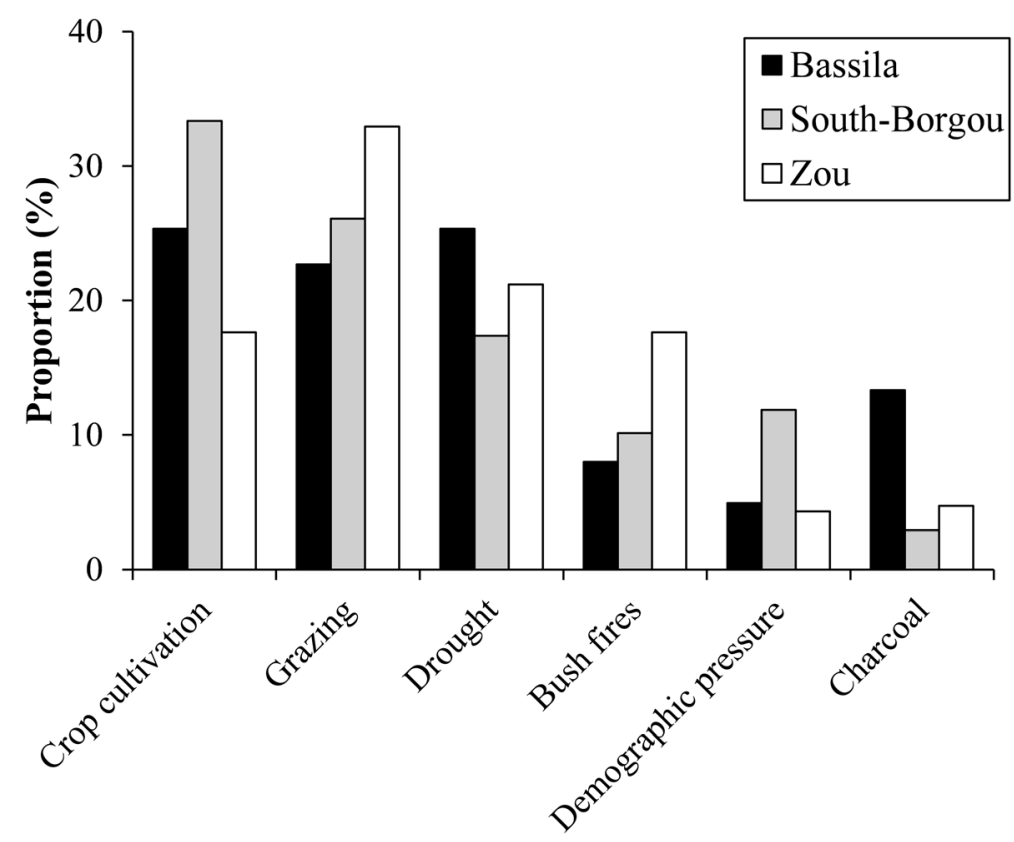

Fig. 12 Factors purported responsible of the decline of the wild spice populations in the Sudano-Guinean zone 


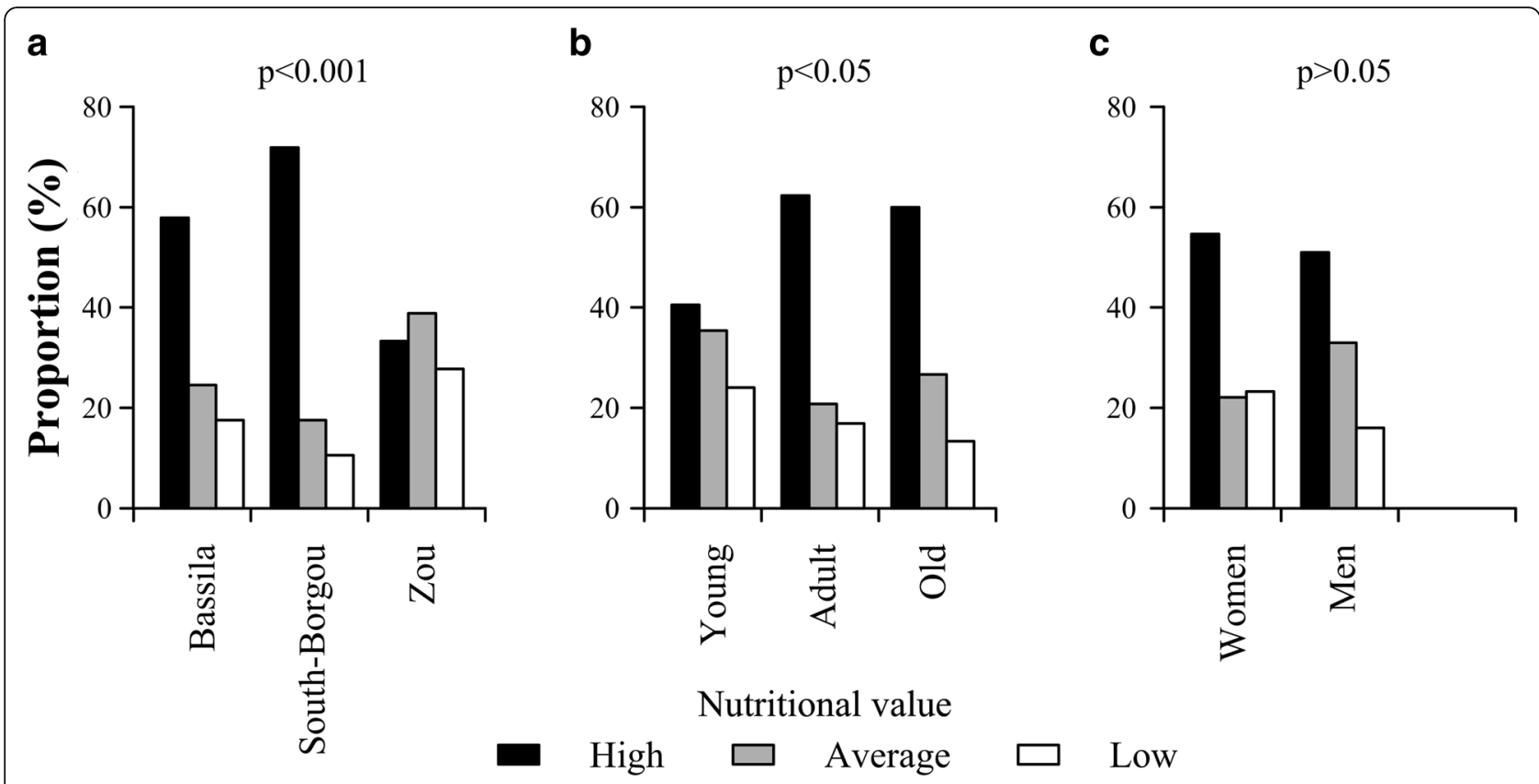

Fig. 13 Local perceptions of the nutritional value of the wild spices. a Phytodistrict. $\mathbf{b}$ Age category. $\mathbf{c}$ Gender. $p=p$ value from Fisher's exact text

spices. For instance, A. alboviolaceum was most culturally important for Fon, L. multiflora for Mahi, and Z. zanthoxyloides for Tchabè from Bassila. Such intercultural variation in wild plant species use is consistent with previous studies in Benin [19, 63, 64]. Irrespective of sociolinguistic group, gender and age categories, the most culturally important uses of the wild spices were for food, medicine and cultural practices respectively. This finding clearly attests that spices are initially intended for food. With respect to gender, the most culturally important use for men was medicinal and to some extent ceremonial, while women, almost exclusively, were specialized in using the spices for food. The medicinal and ceremonial relatedness of preference use values for men could be associated to the cultural custodianship of men in the sociolinguistic groups studied. In most villages in Benin, men are assumed to be the tradition guardian and are often engaged in ceremonial

Table 13 List of top 5 priority wild spices for conservation in the Sudano-Guinean Zone in Benin

\begin{tabular}{|c|c|c|c|c|c|}
\hline Species & PSP & PSPW & CRS & BRS & Total \\
\hline Aframomum alboviolaceum & $x$ & $x$ & $x$ & $x$ & 4 \\
\hline Lippia multiflora & $x$ & $x$ & $x$ & $x$ & 4 \\
\hline Xylopia aethiopica & $x$ & $x$ & $x$ & $x$ & 4 \\
\hline Zanthoxylum zanthoxyloides & $x$ & $x$ & $x$ & $x$ & 4 \\
\hline Monodora tenuifolia & $x$ & $x$ & $x$ & $x$ & 4 \\
\hline
\end{tabular}

PSP point scoring procedure, $P S P W$ point scoring procedure with weighing, $C R S$ compound ranking system, $B R S$ binomial ranking system and magico-religious activities. This makes them more knowledgeable in these use categories. For instance, Monodora tenuifolia, a wild spice used by Mahi men for rituals in convents of traditional divinities, is totally unknown to women of the same sociolinguistic group. Similarly, African black pepper (Piper guineense) fruits constitute an essential component in Fâ rituals [65] and are often harvested from the sacred groves of Badjamè by Adja priests. Meanwhile, Adja women harvested the leaves of the same plant in surrounding of the sacred groves for flavoring soups but none of them knew that the plant they always harvest was actually black pepper plant. As all these roles are generally devoted to men, they may likely have more knowledge of medicinal and ceremonial plants than women. On the other side, women are most involved in performing household labors and would thus be more knowledgeable on food plants and less on ritual or ceremonial plants. The difference of preference of use between men and women confirms the hypothesis of gender division of space and labor within households [59].

Overall, the informant consensus analysis revealed a high level of agreement among the informants for all use categories indicating a more consistent use of wild spices. This opens an avenue for the sustainable management of these neglected resources through promotion of their domestication involving local communities. As it could be expected, the highest degree of agreement was found for food use category, and followed by medicinal uses. This may be due to the high number of use reports 
for only ten wild spices consumed in the study area (Table 7). It indicates that information pertaining to the use of food/edible wild spices is shared among informants in the surveyed communities. More interestingly, men and women shared the same level of agreement suggesting that female informants are as well informed as male informants. Moreover, the degree of consensus varied among the sociolinguistic groups with Idatcha people having the least agreement $\left(F_{\mathrm{ic}}=0.88\right)$. It appeared thus that these people collect randomly wild spices for particular uses contrary to Tchabè from Zou phytodistrict who relied on only two wild spices for all uses $\left(F_{\text {ic }}=0.98\right)$. Therefore, the rarefaction or loss of one of the many wild spices available for Idatcha is expected to have a little impact on the overall use and the traditional practices in this sociolinguistic group [66]. Meanwhile, more attention should be devoted to the two species used by Tchabè in the Zou phytodistrict [67].

The wild spices with high use values were A. alboviolaceum, L. multiflora, A. angustifolium, and Z. zanthoxyloides respectively. The highest UV of $A$. alboviolaceum comes from the fact that the species is a multipurpose plant widespread in savannas across Benin and most farmers use it as wild food and thirst quencher in the field which are often far from the villages. Moreover, many farmers value its stem as string to make bundle of firewood and bind luggage a (Table 12). This emphasizes the key role and value of wild foods in the daily life of agricultural communities [68].

Two of the spices (L. multiflora and Z. zanthoxyloides) were used in the treatment of gastrointestinal diseases, ailments which are common in the study area due to low availability of drinking water and sanitation facilities [69]. In addition to their use as food spice, $Z$. zanthoxyloides and $L$. multiflora were also attributed stimulating effects on milk production in nursing women. This corroborates previous findings of Segnon and Achigan-Dako [70] and Atanasso et al. [71] who reported the same uses for $Z$. zanthoxyloides and L. multiflora respectively.

Considering wild spices use categories, the high number of specific uses (144 uses) as medicine compared to food category (39 uses) contrasts however with the previous use pattern of wild spices: food use category remained first. Nevertheless, this finding is congruent with the statement that indigenous people value wild spices more for their ethnomedicinal uses than for spicing food [52]. Another reason might result from intercultural knowledge gaps in the use of some species. For instance, Fon people did not make food use of $L$. multiflora at all, while the species was highly culturally important for Mahi for food needs. Since home gardens are critical in conserving plant biodiversity, their promotion as home for wild spices should be encouraged, particularly in areas of Bassila occupied by Tchabè. This will help to diversify household incomes, conserve the species, and strengthen the food and nutritional security of rural people.

Most of the respondents acknowledged decline of wild spice populations over the time. Main factors responsible for this decline as perceived by local people were both anthropogenic and natural. Among anthropogenic factors, crop cultivation stood first followed by grazing. This finding is in accordance with a previous study on Sclerocarya birrea where land clearance for agricultural purposes, carving, and drought were the main threatening factors [72].

\section{Priority wild spices for conservation}

In recent years, increasing attention has been given to the prioritization of wild plant species and their conservation in Benin. While the previous prioritization studies undertaken so far have targeted different groups of species such as non-timber forest products (NTFPs) [64], wild edible plants [20], crop wild relatives [47], neglected and underutilized species [73], and timber species, none of these studies has focused on wild spices. The only previous study that listed some wild spices for conservation is the Red List of threatened plant species of Benin [4], with six species (Monodora myristica, Tetrapleura tetraptera, Xylopia aethiopica, X. rubescens, Zanthoxylum gilletii, and $Z$. zanthoxyloides) documented as threatened based on the IUCN criteria [74]. Four of those wild spice taxa were missing from our inventory and the missing taxa included two species (M. myristica and $Z$. gilletii) whose respective ecological range was out of the extent of the study area, and two others that were not recorded from our ethnobotanical inventory. This could also suggest that threat is a temporally dynamic process influenced by several external (human-associated and environment-related) and internal (reproduction, viability, inbreeding, genetic erosion, and adaptability) factors [75], and a species that has a low conservation concern today can become highly threatened in the future [76]. Urgent conservation action to safeguard the wild spices would be the only way to ensure the availability of these resources for the future generations. Indeed, agriculture in Benin and in sub-Saharan Africa in general is characterized by rainfed and low-input subsistence farming practiced by rural households [77], and more new lands are cleared every year for food production, as most soils have low fertility. A step-change in current agricultural system is hence needed if the impact of farming on wild plant species is to be mitigated [78]. However, this does not mean that food production must be neglected ipso facto for the conservation of wild plant species. Rather, policymakers should find a trade-off between agriculture and conservation in order to feed the fast-growing populations 
while preserving wild resources for future generations. For instance, sustainable intensification of agriculture would be an attractive alternative that can reduce considerably agriculture contribution to habitat destruction [79], and increase sustainability and effectivity of conservation actions targeting wild spices.

Although the method and criteria used were not the same, current results partially confirm and are complementary to the ones from Neuenschwander et al. [4], who listed a few wild spices as priority for conservation in Benin. Actually, there are no single approaches to generate lists of species to include in conservation plans. In this study, we adopted a recent approach developed by Brehm et al. [21] and successfully implemented by Idohou et al. [47] in assessing priority crop wild relatives for conservation in Benin. This approach is very flexible and allows combination of several socio-economic and ecological criteria in different methods, in order to achieve the objectives of the study. It differs from the approach used by Teso et al. [80], Berlingeri and Crespo [81], and Khoury et al. [82] to identified priority crop wild relatives for conservation in Spain, Venezuela, and USA respectively. However, the approach is time consuming giving the number of criteria considered and the different methods it combines to overcome the potential subjectivity that may result from attribution of scores and weights to each criterion. Besides, its implementation requires a lot of information that are not often available for most wild species, particularly the ones that are neglected by government and researchers. This being true for the functional group of wild spices in Benin, this prioritization exercise should be updated when more new information will be available on the species. Moreover, results from this approach may not necessarily reflect the conservation significance of each priority species as perceived by local people. This could greatly affect the acceptability and the success of any conservation action of wild spices at local level, since the communities' interests may have been overlooked [20]. Indeed, the criteria used here may not correspond to those used by communities in their evaluation of the value of wild spices and much less to their perception of threatened species.

\section{Conclusion}

This is a pioneer study in the field of wild spices investigation across habitats in Benin. It highlights how geographic location, sociolinguistic groups, and gender influence the traditional knowledge and the subsequent use pattern of the wild spices. Indeed, people in Bassila phytodistrict, especially Tchabè, are more knowledgeable on the use of wild spices. Likewise, male informants value the wild spices much more than women. Domestication and improvement programs of these species should take into account this traditional knowledge. The most culturally important species and uses are all functions of sociolinguistic grouping and vary according to phytodistrict. Based on the local perception of the nutritional value of wild spices, the study revealed that people give them a high nutritional value, while at the same time using them mostly for medicinal purposes. In addition, the wild spices are perceived in decline by local populations, mainly due to high anthropogenic pressures and to some extent drought. Besides, the study provides insights into which species in this study area should be given more priority in an active conservation. For effective conservation and sustainable management of wild spices, scientists must provide substantial data on such aspects as morphological and genetic diversity within the species and breaking of seed dormancy. We proposed the integration of the wild spices into home gardens and agroforestry-based systems in the sociolinguistic areas of Tchabè, in the phytodistrict of Bassila. This will ensure the conservation of the resources while helping the diversification of household incomes and enhancing nutritional and food security.

\section{Abbreviations \\ AIC: Akaike information criteria; ANOSIM: Analysis of similarities; BIC: Bayesian information criteria; BRS: Binomial Ranking System; CA: Correspondence analysis; Cl: Cultural importance index; CRS: Compound Ranking System; $F_{i c}$ : Informants consensus factor; GLM: Generalized linear model; IUCN: International Union for Conservation of Nature; NTFPs: Non-timber forest products; PROTA: Plant Resources of Tropical Africa; PSP: Point Scoring Procedure; PSPW: Point Scoring Procedure with Weighting; SGZ: Sudano-Guinean Zone; TK: Traditional knowledge; UR: Use report; UV: Use value}

\section{Acknowledgements}

The authors gratefully acknowledge the contribution of informants who participated in this research. We are also grateful to our guides and translators for their help in the field. Special thanks to Dr. Elie Padonou and Dr. Marcel Donou for their advice during data analysis. We especially thank Miss Anna Psiaki for the language edition.

\section{Funding}

No funding has been received for the current research project.

\section{Availability of data and materials}

The datasets supporting the conclusions of this article are included within the article and its additional files.

\section{Authors' contributions}

KMK designed the study, collected and analyzed data, and drafted the manuscript. RI and KVS supervised the data analysis and revised the manuscript. CA and $\mathrm{AE}$ improved the manuscript. ACA and AEA contributed to the interpretation of findings and improved the manuscript. All authors read and approved the final manuscript.

Ethics approval and consent to participate

No ethical approval was needed for this study. Prior to data collection, participants gave oral consent to participate in the study.

\section{Consent for publication}

The respondents were informed that their opinions were to be published in a scientific paper and gave their approval. 


\section{Publisher's Note}

Springer Nature remains neutral with regard to jurisdictional claims in published maps and institutional affiliations.

\section{Author details}

'Laboratoire de Génétique Moléculaire et d'Analyse des Génomes (LGMAG), Faculté des Sciences et Techniques, Université d'Abomey-Calavi, BP 142, Abomey-Calavi, Bénin. 'Laboratoire de Biomathématiques et d'Estimations Forestières (LABEF), Faculté des Sciences Agronomiques, Université d'Abomey-Calavi, 04BP 1525, Cotonou, Bénin. ${ }^{3}$ Laboratoire d'Ecologie Appliquée (LEA), Faculté des Sciences Agronomiques, Université d'Abomey-Calavi, 01BP 526, Tri postal, Cotonou, Bénin. ${ }^{4}$ Regional Universities Forum for Capacity Building in Agriculture (RUFORUM), P.O. Box 16811, Wandegeya, Kampala, Uganda. ${ }^{5}$ Herbier National, Département de Biologie végétale, Faculté des Sciences et Techniques, Université d'Abomey-Calavi, 01BP 4521, Cotonou, Bénin.

Received: 20 June 2018 Accepted: 29 October 2018

Published online: 15 November 2018

\section{References}

1. Bini L, Alexandre J, Diniz-Filho F, Carvalho P, Pinto MP, Rangel TFL. Lomborg and the litany of biodiversity crisis: what the peer-reviewed literature says. Conserv Biol. 2005;19:1301-5.

2. Stanley D, Voeks R, Short L. Is non-timber forest product harvest sustainable in the less developed world? A systematic review of the recent economic and ecological literature. Ethnobiol Conserv. 2012;1:1-39.

3. Hunyet $\mathrm{O}$. Rapport de l'étude d'inventaire de la biodiversité des forêts sacrées des sites RAMSAR 1017 et 1018 du Bénin. Benin: Organisation Internationale des Bois Tropicaux; 2013. p. 88.

4. Neuenschwander P, Sinsin B, Goergen G. Protection de la Nature en Afrique de I'Ouest: Une Liste Rouge pour le Bénin. Nature Conservation in West Africa: Red List for Benin. Ibadan: International Institute of Tropical Agriculture; 2011.

5. Heubach K, Wiitg R, Nuppenau E, Hahn K. The economic importance of nontimber forest products (NTFPs) to livelihood maintenance of rural west African communities: a case study from northern Benin. Ecol Econ. 2011;70:1991-2001.

6. Shackleton S, Gumbo D. Contribution of non-wood forest products to livelihoods and poverty alleviation. In: Chidumayo EN, Gumbo DJ, editors. The dry forests and woodlands of Africa: managing for products and services. London: Earthscan forestry library; 2010.

7. Balemie K, Kebebew F. Ethnobotanical study of wild edible plants in Derashe and Kucha Districts, South Ethiopia. J Ethnobiol Ethnomed. 2006;2:53.

8. Sanchez AC, Fandohan B, Assogbadjo AE, Sinsin B. A countrywide multiethnic assessment of local communities' perception of climate change in Benin (West Africa). Clim Dev. 2012;4:114-28.

9. Vranken I, Djibu Kabulu JP, Munyemba Kankumbi F, Mama A, lyongo Waya Mongo L, Bamba I, Laghmouch M, Bogaert J. Ecological impact of habitat loss on African landscapes and biodiversity. In: Daniels JA, editor. Advances in Environmental Research, vol. 14. New York: Nova Science Publishers, Inc; 2011. p. 367-88

10. Farrell KT. Spices, condiments and seasonings: Springer Science \& Business Media; 1998.

11. Chi S-P, Wu Y-C. Spices and seasonings. In: Toldrá F, Hui YH, Astiasaran I, Sebranek J, Talon R, editors. Handbook of fermented meat and poultry. 2nd ed: John Wiley \& Sons; 2015. p. 87-100

12. Kaefer CM, Milner JA. The role of herbs and spices in cancer prevention. J Nutr Biochem. 2008;19:347-61.

13. Srinivasan K. Plant foods in the management of diabetes mellitus: spices as beneficial antidiabetic food adjuncts. Int J Food Sci Nutr. 2005;56:399-414.

14. Srinivasan K. Role of spices beyond food flavoring: nutraceuticals with multiple health effects. Food Rev Int. 2005;21:167-88.

15. Al-Jasass FM, Al-Jasser MS. Chemical composition and fatty acid content of some spices and herbs under Saudi Arabia conditions. Sci World J. 2012;2012.

16. Couly C, Sist P. Use and knowledge of forest plants among the Ribeirinhos, a traditional Amazonian population. Agrofor Syst. 2013;87:543-54.

17. Albuquerque UP, Hanazaki N. Five problems in current ethnobotanical research - and some suggestions for strengthening them. Hum Ecol. 2009; 37:653-61.

18. Brandt R, Mathez-Stiefel S-L, Lachmuth S, Hensen I, Rist S. Knowledge and valuation of Andean agroforestry species: the role of sex, age, and migration among members of a rural community in Bolivia. J Ethnobiol Ethnomed. 2013;9:83.

19. Houehanou TD, Assogbadjo AE, Glèlè Kakaï R, Houinato $M$, Sinsin B. Valuation of local preferred uses and traditional ecological knowledge in relation to three multipurpose tree species in Benin (West Africa). Forest Policy Econ. 2011;13:554-62.

20. N'Danikou S, Achigan-Dako EG, Wong JL. Eliciting local values of wild edible plants in southern Bénin to identify priority species for conservation. Econ Bot. 2011;65:381-95.

21. Magos Brehm J, Maxted N, Martins-Loução MA, Ford-Lloyd BV. New approaches for establishing conservation priorities for socio-economically important plant species. Biodivers Conserv. 2010;19:2715-40.

22. Adomou AC, Sinsin B, Van der Maesen LJG. Phytosociological and chorological approaches to phytogeography: a meso-scale study in Benin. Syst Geogr Plants. 2006;76:155-78.

23. Adomou AC. Vegetation patterns and environmental gradient in Benin: implications for biogeography and conservation, Ph.D. Thesis: Wageningen University; 2005

24. Adomou AC. Phytogéographie du Bénin. Phytogeography of Benin. In: Neuenschwander P, Sinsin B, Goergen G, editors. Protection de la natire en Afrique de l'Ouest: Une Liste Rouge pour le Bénin Nature conservation in West Africa: Red List for Benin. Ibadann: International Institute of Tropical Agriculture; 2011. p. 365.

25. Sinsin B, Kampmann D, Thiombiano A, Konaté S. Atlas de la Biodiversité de I'Afrique de l'Ouest. Bénin, Cotonou \& Frankfurt/Main: Tome I; 2010.

26. INSAE: RGPH4 : Que retenir des effectifs de population en 2013? 2015

27. Adam K, Boko M. Le Bénin. Paris: Flamboyant EDICEF; 1993.

28. Sinsin B, Matig OE, Assogbadjo A, Gaoué O, Sinadouwirou T. Dendrometric characteristics as indicators of pressure of Afzelia africana Sm. dynamic changes in trees found in different climatic zones of Benin. Biodivers Conserv. 2004;13:1555-70.

29. Akoègninou $A$, van der Burg WJ, van der Maesen $L G$, editors. Flore Analytique du Bénin. Wageningen: Backhuys Publishers; 2006.

30. Dagnelie P. Statistiques théoriques et appliquées. Brussels: De Boeck et Larcier; 1998.

31. da Fonseca-Kruel VS, de Araujo DSD, de Sá CFC, Peixoto AL. Quantitative ethnobotany of a restinga forest fragment in Rio de Janeiro, Brazil. Rodriguésia. 2009;60:187-202.

32. IUCN. The IUCN Red List of Threatened Species. Version 2017-2. http:// www.iucnredlist.org/. Accessed 5 Nov 2018.

33. PROTA. Plant Resources of Tropical Africa. https://www.prota4u.org/ database/. Accessed 5 Nov 2018

34. Arbonnier M. Arbres, arbustes et lianes des zones sèches d'Afrique de I'Ouest. 2ème edn. France: CIRAD - MNHN; 2002.

35. White $F$. The vegetation of Africa, a descriptive memoir to accompany the UNESCO/AETFAT/UNSO vegetation map of Africa (3 Plates, Northwestern Africa, Northeastern Africa, and Southern Africa, 1: 5,000,000). Paris: Unesco; 1983.

36. Colwell RK. Estimate S: Statistical estimation of species richness and shared species from samples. Version 9. 2013. Persistent URL http://purl.oclc.org/ estimates. Accessed 3 Nov 2018.

37. Williams VL, Edward T, Witkowski F, Balkwill K. The use of incidence-based species richness estimators, species accumulation curves and similarity measures to appraise ethnobotanical inventories from South Africa. Biodivers Conserv. 2007:16:2495.

38. Dytham C. Choosing and using statistics: a biologist's guide: John Wiley \& Sons; 2011.

39. Zar JH. Biostatistical analysis: Pearson new international edition: Pearson Higher Ed; 2013

40. Clarke KR. Non-parametric multivariate analyses of changes in community structure. Austral Ecol. 1993;18:117-43.

41. Tardio J, Pardo-de-Santayana M. Cultural importance indices: a comparative analysis based on the useful wild plants of southern Cantabria (northern Spain). Econ Bot. 2008;62:24-39.

42. Heinrich M, Ankli A, Frei B, Weimann C, Sticher O. Medicinal plants in Mexico: Healers' consensus and cultural importance. Soc Sci Med. 1998;47:1859-71.

43. Gazzaneo LRS, De Lucena RFP, de Albuquerque UP. Knowledge and use of medicinal plants by local specialists in an region of Atlantic Forest in the state of Pernambuco (northeastern Brazil). J Ethnobiol Ethnomed. 2005;1:9.

44. Paniagua Zambrana NY, Bussmann RW, Hart RE, Moya Huanca AL, Ortiz Soria G, Ortiz Vaca M, Ortiz Álvarez D, Soria Morán J, Soria Morán M, Chávez S, et al. Traditional knowledge hiding in plain sight - twenty-first century ethnobotany of the Chácobo in Beni, Bolivia. J Ethnobiol Ethnomed. 2017;13:57. 
45. Rossato SC, De LeitãO-Filho HF, Begossi A. Ethnobotany of caiçaras of the Atlantic Forest coast (Brazil). Econ Bot. 1999;53:387-95.

46. Phillips O, Gentry AH. The useful plants of Tambopata, Peru: I. statistical hypotheses tests with a new quantitative technique. Econ Bot. 1993;47:15-32.

47. Idohou R, Assogbadjo AE, Fandohan B, Gouwakinnou GN, Glèlè Kakaï RL, Sinsin B, Maxted N. National inventory and prioritization of crop wild relatives: case study for Benin. Genet Resour Crop Evol. 2012;60:1337-52.

48. R Core Team. R: a language and environment for statistical computing. Vienna: R Foundation for Statistical Computing; 2018.

49. Ogle D. FSA: fisheries stock analysis, R package version 0814; 2017. p. 13.

50. Oksanen J, Blanchet FG, Friendly M, Kindt R, Legendre P, McGlinn D, Minchin PR, O'Hara B, Simpson GL, Solymos P, et al: vegan: Community Ecology Package. R package version 24-3 2017, https://cran.r-project.org/ package $=$ vegan

51. Lê S, Josse J, Husson F. FactoMineR: an R package for multivariate analysis. J Stat Softw. 2008;25:1-18.

52. Ndukwu BC, Ben-Nwadibia NB. Ethnomedicinal aspects of plants used as spices and condiments in the Niger Delta area of Nigeria. Ethnobot Leaflets. 2005;2005:10

53. Poorter L. Biodiversity of West African forests: an ecological atlas of woody plant species: $\mathrm{CABl}$; 2004

54. Gaoue OG, Ticktin T. Fulani knowledge of the ecological impacts of Khaya senegalensis (Meliaceae) foliage harvest in Benin and its implications for sustainable harvest. Econ Bot. 2009;63:256-70.

55. Houessou LG, Teka O, Imorou IT, Lykke AM, Sinsin B. Land use and landcover change at " $\mathrm{W}$ " biosphere reserve and its surroundings areas in Benin Republic (West Africa). Environ Nat Resour Res. 2013;3:87.

56. Moreira IC, Roque NF, Vilegas W, Zalewski CA, Lago JH, Funasaki M. Genus xylopia (Annonaceae): chemical and biological aspects. Chem Biodivers. 2013;10:1921-43.

57. Assogbadjo AE, Fandohan B, Glèlè Kakaï R, Kyndt T, Hardy OJ, Gheysen G, Sinsin B. Genetic evidence of the contribution of ethnic migrations to the propagation and persistence of the rare and declining scrambling shrub Caesalpinia bonduc L. Hum Ecol. 2011;40:117-28.

58. Souto T, Ticktin T. Understanding interrelationships among predictors (age, gender, and origin) of local ecological Knowledge1. Econ Bot. 2012;66:149-64.

59. Voeks RA. Are women reservoirs of traditional plant knowledge? Gender, ethnobotany and globalization in northeast Brazil. Singap J Trop Geogr. 2007;28:7-20.

60. Honfo H, Tovissodé FC, Gnanglè C, Mensah S, Salako VK, Assogbadjo AE, Agbangla C, Glèlè Kakaï R. Traditional knowledge and use value of bamboo in southeastern Benin: implications for sustainable management. Ethnobot Res Appl. 2015;14:139-53.

61. Salako KV, Moreira F, Gbedomon RC, Tovissodé F, Assogbadjo AE, Glèlè Kakaï RL. Traditional knowledge and cultural importance of Borassus aethiopum Mart. In Benin: interacting effects of socio-demographic attributes and multi-scale abundance. J Ethnobiol Ethnomed. 2018;14:36.

62. Camou-Guerrero A, Reyes-García V, Martínez-Ramos M, Casas A. Knowledge and use value of plant species in a Rarámuri community: a gender perspective for conservation. Hum Ecol. 2008;36:259-72.

63. Fandohan B, Assogbadjo AE, Glèlè Kakaï R, Kyndt T, De Caluwé E, Codjia JTC, Sinsin B. Women's traditional knowledge, use value, and the contribution of tamarind (Tamarindus indica L.) to rural households' cash income in Benin. Econ Bot. 2010;64:248-59.

64. Vodouhê FG, Coulibaly O, Greene C, Sinsin B. Estimating the local value of non-timber forest products to pendjari biosphere reserve dwellers in Benin. Econ Bot. 2009;63:397-412.

65. Quiroz D, van Andel T. Evidence of a link between taboos and sacrifices and resource scarcity of ritual plants. J Ethnobiol Ethnomed. 2015;11:5.

66. Nascimento ALB, Júnior WSF, Ramos MA, de Medeiros PM, Soldati GT, Santoro FR, Albuquerque UP. Utilitarian redundancy: conceptualization and potential applications in ethnobiological research. In: Evolutionary ethnobiology. Chicago: Springer, Cham; 2015. p. 121-30.

67. Rashid N, Gbedomon RC, Ahmad M, Salako VK, Zafar M, Malik K. Traditional knowledge on herbal drinks among indigenous communities in Azad Jammu and Kashmir, Pakistan. J Ethnobiol Ethnomed. 2018;14.

68. Bharucha Z, Pretty J. The roles and values of wild foods in agricultural systems. Philos Trans R Soc Lond Ser B Biol Sci. 2010;365:2913-26.

69. Gross $E$, Günther I. Why do households invest in sanitation in rural Benin: health, wealth, or prestige? Water Resour Res. 2014;50:8314-29.
70. Segnon AC, Achigan-Dako EG. Comparative analysis of diversity and utilization of edible plants in arid and semi-arid areas in Benin. J Ethnobiol Ethnomed. 2014;10:80

71. Atanasso JA, Chadare FJ, Padonou EA, Ahouansinkpo E, Koura K, Houehanou T, Assogbadjo AE, Glèlè Kakaï R, Sinsin B. Habitats and utilizations of Lippia multiflora moldenke: local perception of four ethnic groups from Benin (West Africa). Agron Afr. 2017;29:111-20.

72. Gouwakinnou GN, Lykke AM, Assogbadjo AE, Sinsin B. Local knowledge, pattern and diversity of use of Sclerocarya birrea. J Ethnobiol Ethnomed. 2011;7:8

73. Dansi A, Vodouhe R, Azokpota P, Yedomonhan H, Assogba P, Adjatin A, Loko YL, Dossou-Aminon I, Akpagana K. Diversity of the neglected and underutilized crop species of importance in Benin. ScientificWorldJournal. 2012;2012:932947

74. The IUCN Red List Categories and Criteria (version 3.1). http://www. iucnredlist.org/documents/RedListGuidelines.pdf. Accessed 3 Nov 2018.

75. Chen Y, Yang X, Yang Q, Li D, Long W, Luo W. Factors affecting the distribution pattern of wild plants with extremely small populations in Hainan Island, China. PLoS One. 2014;9:e97751.

76. Agbani PO, Kafoutchoni KM, Salako KV, Gbedomon RC, Kegbe AM, Karen H, Sinsin B. Traditional ecological knowledge-based assessment of threatened woody species and their potential substitutes in the Atakora mountain chain, a threatened hotspot of biodiversity in northwestern Benin, West Africa. J Ethnobiol Ethnomed. 2018;14:21.

77. Trimmer JT, Bauza V, Byrne DM, Lardizabal A, Guest JS. Harmonizing goals for agricultural intensification and human health protection in sub-Saharan Africa. Trop Conserv Sci. 2017:10. https://doi.org/10.1177/1940082917720666.

78. Balmford A, Green R, Phalan B. What conservationists need to know about farming. Proc R Soc B. 2012. https://doi.org/10.1098/rspb.2012.0515.

79. Pretty J, Toulmin C, Williams S. Sustainable intensification in African agriculture. Int J Agric Sustain. 2011;9:5-24.

80. Teso MR, Torres M, Parra-Quijano M, Iriondo J. Prioritization of crop wild relatives in Spain: Crop wild relative; 2012. p. 18.

81. Berlingeri C, Crespo MB. Inventory of related wild species of priority crops in Venezuela. Genet Resour Crop Evol. 2012;59:655-81.

82. Khoury CK, Greene S, Wiersema J, Maxted N, Jarvis A, Struik PC. An inventory of crop wild relatives of the United States. Crop Sci. 2013;53:1496-508.

Ready to submit your research? Choose BMC and benefit from:

- fast, convenient online submission

- thorough peer review by experienced researchers in your field

- rapid publication on acceptance

- support for research data, including large and complex data types

- gold Open Access which fosters wider collaboration and increased citations

- maximum visibility for your research: over $100 \mathrm{M}$ website views per year

At BMC, research is always in progress.

Learn more biomedcentral.com/submissions 